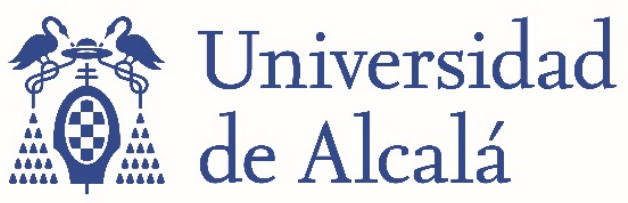

BIBLIOTECA

Document downloaded from the institutional repository of the University of Alcala: http://dspace.uah.es/

This is a postprint version of the following published document:

Fuentes Paniagua, M.E., Hernández Ros, J.M., Soliveri De Carranza, J., Copa Patiño, J.L., Sánchez-Nieves Fernández, J. \& Mata De La Mata, Francisco J. De La 2017, "Strategies for penicillin V dendronization with cationic carbosilane dendrons and study of antibacterial properties", Canadian Journal of Chemistry, vol. 95, no. 9, pp. 927-934.

Available at http://dx.doi.org/10.1139/cjc-2017-0059

(C) 2017 Elsevier
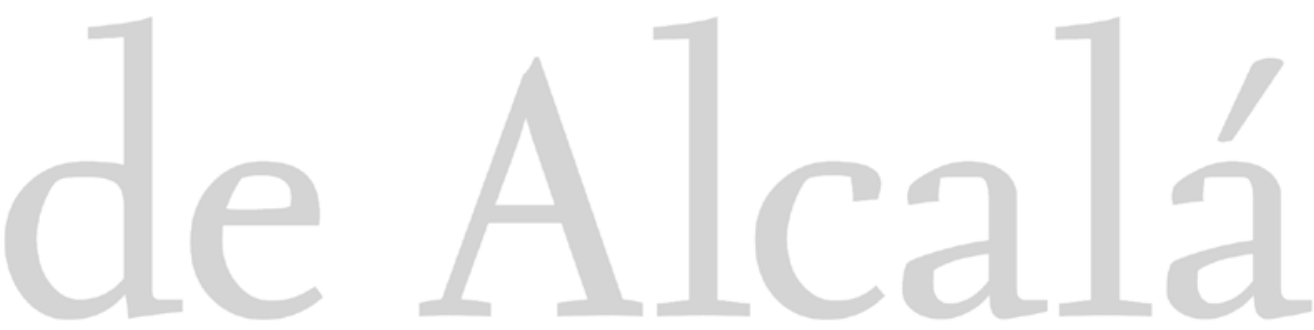

(Article begins on next page)

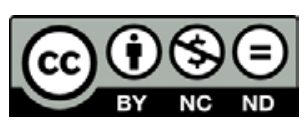

This work is licensed under a

Creative Commons Attribution-NonCommercial-NoDerivatives

4.0 International License. 


\title{
Strategies for penicillin V dendronization with cationic carbosilane dendrons and study of antibacterial properties
}

\author{
Elena Fuentes-Paniagua, José M. Hernández-Ros, Juan Soliveri, José L. Copa-Patiño, Rafael Gómez, \\ Javier Sánchez-Nieves, and F. Javier de la Mata
}

\begin{abstract}
Strategies to synthesize a cationic carbosilane dendron containing the antibiotic penicillin V potassium salt (PenVK) at the focal point are discussed. The preparation of such a compound requires the use of systems with no donor atoms such as $\mathrm{N}$ or $\mathrm{S}$ in their framework, because their presence favours the rupture of the penicillin $\beta$-lactam ring. The antibacterial activity of the new dendron containing ammonium groups, at the periphery, and the PenV moiety, at the focal point, against grampositive Staphylococcus aureus strains was evaluated. These results were compared with those obtained for free PenVK, a related cationic dendron without a penicillin moiety at the focal point, and also compared with an equimolar mixture of this last dendron with free PenV. The data obtained indicate that, on one hand, the conjugation or interaction of PenV with cationic dendrons reduces its activity in comparison with free PenVK. On the other hand, the penicillin dendron is able to release the antibiotic in the presence of esterease, due to the breaking of the ester bond in this derivative.
\end{abstract}

Key words: dendritic molecules, carbosilane dendrons, antibacterial, penicillin, antibiotic.

Résumé : Il est question dans le présent article de stratégies pour synthétiser un dendron de carbosilane cationique contenant en son point focal le sel potassique de la pénicilline $\mathrm{V}$ (PenVK), un antibiotique. La préparation d'un tel composé requiert l'emploi de systèmes dont la structure est dépourvue de donneurs d'atomes, tels que l'azote $(\mathrm{N})$ ou le soufre $(\mathrm{S})$, car ceux-ci causent la rupture du cycle $\beta$-lactame de la pénicilline. L'activité antimicrobienne de ce nouveau dendron dotés de groupes ammonium en périphérie et du groupement PenV au point focal a été évaluée en présence de souches de Staphylococcus aureus à gram positif. Nous avons comparé ces résultats à ceux qui ont été obtenus pour la PenVK libre, pour un dendron cationique apparenté sans groupement pénicilline au point focal, ainsi que pour un mélange équimolaire de ce dernier dendron avec la PenV libre. Les données obtenues indiquent que l'activité de la PenV conjuguée aux dendrons cationiques ou en présence de ceux-ci est réduite par rapport à celle de la PenVK libre. Par ailleurs, nous avons montré qu'en présence d'estérase, le dérivé pénicilline-dendron est capable de libérer l'antibiotique par clivage de sa liaison ester. [Traduit par la Rédaction]

Mots-clés : molécules dendritiques, dendrons de carbosilane, antibactérien, pénicilline, antibiotique.

\section{Introduction}

The widespread use and misuse of antibiotics have favored the appearance of antibiotic-resistant bacteria, ${ }^{1-3}$ creating a major public health concern. ${ }^{4}$ The problem is worsened by the ability of bacteria to create biofilms, ${ }^{5}$ which are involved in the majority of infection diseases caused by bacteria. ${ }^{6}$ Thereby, the need of finding compounds with non-specific antibacterial activity to fight resistance and (or) reduce antibiotic dependence is a priority. ${ }^{7,8}$

The bacterial cell walls are formed with negative lipoproteins and divalent cations such as $\mathrm{Mg}^{2+}$ and $\mathrm{Ca}^{2+}$ acting as glue. ${ }^{9}$ Thus, quaternary ammonium salts (QAS) have become popular antimicrobials due to their ability to replace these cations and destroy the cell wall. ${ }^{9-11}$ Another advantage of some QAS is their solubility in water, which allows them to kill bacteria in water solution. ${ }^{12}$ The incorporation of QAS to polymers generates polycations that present a high surface charge. The multivalency of these polyammonium macromolecules such as polymers, ${ }^{13}$ hyperbranched polymers, ${ }^{14}$ and dendrimers ${ }^{15,16}$ increases the activity with respect to monofunctional molecules. .,13,17 $^{-13}$

Dendrimers and dendrons are multibranched macromolecules designed step by step, which leads to well-defined structures. ${ }^{18-20}$ Dendrimers are spherical molecules, whereas dendrons are coneshaped molecules, presenting an extra active moiety, the focal point, that can be used to attach a second functionality or to dendronize materials. The well-known structures of these systems make it easier to establish structure-activity relationships. Several types of ammonium dendrimers, depending on their dendritic structure, have shown antibacterial properties. ${ }^{21-25}$ Their activity is increased by the presence of hydrophobic chains, which enables their penetration into the phospholipid bilayer, leading to the disintegration of the bacterial membrane. ${ }^{11,26}$ Regarding dendrons, antimicrobial studies are scarce, ${ }^{27}$ and usually, they are associated to the generation of dendronized materials, ${ }^{28-30}$ because the focal point is an excellent anchorage position for functionalization.

Received 27 January 2017. Accepted 10 March 2017.

E. Fuentes-Paniagua, R. Gómez, J. Sánchez-Nieves, and F.J. de la Mata. Departamento de Química Orgánica y Química Inorgánica, Campus Universitario, Universidad de Alcalá, Alcalá de Henares, Spain; Networking Research Center on Bioengineering, Biomaterials and Nanomedicine (CIBER-BBN), Spain.

J.M. Hernández-Ros, J. Soliveri, and J.L. Copa-Patiño. Departamento de Biomedicina y Biotecnología, Campus Universitario, Universidad de Alcalá, Alcalá de Henares, Spain.

Corresponding author: Javier Sánchez-Nieves (email: javier.sancheznieves@uah.es).

This paper is part of a Special Issue entitled "Recent development in dendrimers syntheses and applications".

Copyright remains with the author(s) or their institution(s). Permission for reuse (free in most cases) can be obtained from RightsLink. 
Dendrimers have also been employed as drug carriers by electrostatic interaction between drugs and surface groups, conjugation of drug to dendrimer, or by encapsulation of drug inside a hyperbranched framework. ${ }^{31,32}$ For example, it has been reported that some dendrimers enhance solubility and activity of antibiotics. ${ }^{33-37}$ Moreover, a synergistic effect has been observed for some combinations of dendrimers with antibacterial properties and antibiotics. ${ }^{38-40}$

One type of dendrimers is based on carbosilane framework, which contains very low polar C-C and Si-C bonds. ${ }^{41,42}$ The decoration of the surface of dendrimers with ammonium functions introduces antimicrobial properties and water solubility to these dendrimers. ${ }^{43-46}$ Recently, we published an evaluation of antibacterial activity of cationic carbosilane dendrimers and dendrons by comparing generation, core of dendrimers, focal point of dendrons, and type of ammonium groups. ${ }^{47}$ These results highlight the good activity obtained for low-generation systems (generation one for dendrimers and generation two for dendrons with six and four ammonium groups, respectively) against both gram-positive and gram-negative bacteria and also against resistant $S$. aureus strains. Moreover, these systems did not generate resistance after continuous treatments. We also reported the synergy produced after the combination of a cationic dendrimer with an amoebicide compound (chlorhexidine digluconate). ${ }^{48}$

Taking into account these results, we have considered the evaluation of cationic carbosilane dendrons of second generation as antibiotic carriers, as it could be expected that combination of biocide compounds with different modes of action could act synergistically. ${ }^{49}$ As an antibiotic, we have chosen a penicillin derivative (penicillin V, PenV) for its simplicity and the presence of one carboxylate moiety. This anionic group will be used to interact electrostatically with the cationic dendrons ${ }^{50}$ or to allow conjugation to the dendron employing an adequate group at the focal point. ${ }^{51}$ The synthetic procedure to obtain the new dendrons and also the difficulties found to do it, their characterization, and antibacterial activity against $S$. aureus are discussed.

\section{Experimental}

\section{General considerations}

All reactions were carried out under inert atmosphere, and solvents were purified from appropriate drying agents when necessary. NMR spectra were recorded on a Varian Unity VXR-300 (300.13 $\left.\left({ }^{1} \mathrm{H}\right), 75.47\left({ }^{13} \mathrm{C}\right) \mathrm{MHz}\right)$ or on a Bruker AV400 (400.13 $(1 \mathrm{H})$, $\left.100.60\left({ }^{13} \mathrm{C}\right), 40.56\left({ }^{15} \mathrm{~N}\right), 79.49\left({ }^{29} \mathrm{Si}\right) \mathrm{MHz}\right)$. Chemical shifts $(\delta)$ are given in ppm. ${ }^{1} \mathrm{H}$ and ${ }^{13} \mathrm{C}$ resonances were measured relative to internal deuterated solvent peaks considering TMS $=0 \mathrm{ppm}$; meanwhile, ${ }^{29} \mathrm{Si}$ resonances were measured relative to external TMS employing ${ }^{1} \mathrm{H}^{29} \mathrm{Si}$ HMBC experiments. When necessary, assignment of resonances was done from HSQC, HMBC, COSY, TOCSY, and NOESY NMR experiments. Thiol-ene reactions were carried out employing a HPK $125 \mathrm{~W}$ mercury lamp from Heraeus Noblelight with maximum energy at $365 \mathrm{~nm}$, in normal glassware under an inert atmosphere. Elemental analyses were performed on a LECO CHNS-932. Mass spectra were obtained from an Agilent 6210. Compounds $\mathrm{HS}\left(\mathrm{CH}_{2}\right)_{2} \mathrm{NMe}_{2} \cdot \mathrm{HCl}$ 2,2'-dimethoxy-2-phenylacetophenone (DMPA), MeI, $\mathrm{HSiMe}_{2} \mathrm{Cl}, \mathrm{HSiMeCl}{ }_{2}, \mathrm{LiAlH}_{4}, \mathrm{NaHCO}_{3}$, penicillin $\mathrm{V}$ potassium salt (PenVK), platinum(0)-1,3-divinyl-1,1,3,3-tetramethyldisiloxane complex solution (Karstedt's catalyst), and porcine liver esterease were obtained from commercial sources. Compounds $\mathrm{NH}_{2} \mathrm{G}_{n}\left(\mathrm{NMe}_{2}\right)_{m},{ }^{52}$ $\left[\mathrm{NH}_{2} \mathrm{G}_{n}\left(\mathrm{~S}-\mathrm{NMe}_{3}\right)_{m}\right]^{m+1},{ }^{47} \mathrm{ClG}_{1} \mathrm{~V}_{2},{ }^{53}$ and $\mathrm{ClG}_{1} \mathrm{~A}_{2}{ }^{54}$ were synthesized as published.

\section{Synthesis of selected compounds}

The syntheses of all compounds are described in the Supplementary data, with only a selection mentioned herein.

\section{$\mathrm{ClG}_{1}\left(\mathrm{Si}-\mathrm{NMe}_{2}\right)_{2}(\mathbf{1 1})$}

An excess of allyl-dimethylamine $(0.21 \mathrm{~mL}, 1.76 \mathrm{mmol})$ and two drops of Karsted's catalyst were added to a solution of $\mathrm{ClG}_{1}(\mathrm{SiH})_{2}$ (6) $(0.145 \mathrm{~g}, 0.44 \mathrm{mmol})$ in THF $(2 \mathrm{~mL})$. The reaction mixture was heated at $80{ }^{\circ} \mathrm{C}$ in a sealed ampoule under inert atmosphere for one night and then evaporated to dryness to remove the solvent and residual allyl-dimethylamine. Afterwards, hexane $(10 \mathrm{~mL})$ was added, and the solution was filtered through active carbon and dried under vacuum to yield 11 as a pale yellow oil (0.194 g, 88\%).

${ }^{1} \mathrm{H} \mathrm{NMR}\left(\mathrm{CDCl}_{3}\right): \delta-0.06\left(\mathrm{~s}, 12 \mathrm{H}, \mathrm{SiMe} e_{2}\right), 0.04(\mathrm{~s}, 3 \mathrm{H}, \mathrm{SiMe}), 0.44(\mathrm{t}$, $\left.J_{\mathrm{a}}=8.4 \mathrm{~Hz}, 4 \mathrm{H}, \mathrm{SiCH}_{2} \mathrm{CH}_{2} \mathrm{CH}_{2} \mathrm{~N}\right), 0.57\left(\mathrm{~m}, 10 \mathrm{H}, \mathrm{SiCH}_{2} \mathrm{CH}_{2} \mathrm{CH}_{2} \mathrm{Si}\right.$ and $\left.\mathrm{ClCH}_{2} \mathrm{CH}_{2} \mathrm{CH}_{2} \mathrm{Si}\right), 1.29\left(\mathrm{~m}, 4 \mathrm{H}, \mathrm{SiCH}_{2} \mathrm{CH}_{2} \mathrm{CH}_{2} \mathrm{Si}\right), 1.42(\mathrm{~m}, 4 \mathrm{H}$, $\left.\mathrm{SiCH}_{2} \mathrm{CH}_{2} \mathrm{CH}_{2} \mathrm{~N}\right), 1.72\left(\mathrm{~m}, 2 \mathrm{H}, \mathrm{ClCH}_{2} \mathrm{CH}_{2}\right), 2.19\left(\mathrm{~m}, 16 \mathrm{H}, \mathrm{CH}_{2} \mathrm{NMe}_{2}\right)$, $3.47\left(\mathrm{t}, \mathrm{J}_{\mathrm{b}}=6.9 \mathrm{~Hz}, 2 \mathrm{H}, \mathrm{ClCH}_{2}\right) \cdot{ }^{13} \mathrm{C}\left\{{ }^{1} \mathrm{H}\right\} \mathrm{NMR}\left(\mathrm{CDCl}_{3}\right): \delta-5.2(\mathrm{SiMe})$, -3.4 $\left(\mathrm{SiMe}_{2}\right), 11.6\left(\mathrm{ClCH}_{2} \mathrm{CH}_{2} \mathrm{CH}_{2} \mathrm{Si}\right), 12.8\left(\mathrm{SiCH}_{2} \mathrm{CH}_{2} \mathrm{CH}_{2} \mathrm{~N}\right), 18.3,18.5$ and $20.0\left(\mathrm{SiCH}_{2} \mathrm{CH}_{2} \mathrm{CH}_{2} \mathrm{Si}\right), 22.1\left(\mathrm{SiCH}_{2} \mathrm{CH}_{2} \mathrm{CH}_{2} \mathrm{NMe}_{2}\right), 27.7\left(\mathrm{ClCH}_{2} \mathrm{CH}_{2}\right)$, $45.5\left(-\mathrm{NMe}_{2}\right), 48.1\left(\mathrm{ClCH}_{2}\right), 63.4\left(\mathrm{CH}_{2} \mathrm{NMe}_{2}\right)$. MS: $[\mathrm{M}+\mathrm{H}]^{+}=493.4 \mathrm{uma}$ (calcd = 493.4 uma). Anal. Calcd for $\mathrm{C}_{24} \mathrm{H}_{57} \mathrm{ClN}_{2} \mathrm{Si}_{3}(493.43 \mathrm{~g} / \mathrm{mol})$ : $\mathrm{C}$, 58.42; H, 11.64; N, 5.68; Exp.: C, 58.89; H, 11.57; N, 5.81.

\section{$\mathrm{ClG}_{1}\left(\mathrm{Si}_{-} \mathrm{NMe}_{3} \mathrm{I}\right)_{2}(\mathbf{1 3})$}

A mixture of $11(0.220 \mathrm{~g}, 0.44 \mathrm{mmol})$ and $\mathrm{MeI}(0.11 \mathrm{~mL}, 1.76 \mathrm{mmol})$ in THF $(50 \mathrm{~mL})$ were stirred for $16 \mathrm{~h}$. Afterward, volatiles were removed under vacuum, and the remaining solid was washed with $\mathrm{Et}_{2} \mathrm{O}(50 \mathrm{~mL})$, obtaining 13 as a white solid $(0.300 \mathrm{~g}, 87 \%)$.

${ }^{1} \mathrm{H}$ NMR (DMSO-d $\left.{ }_{6}\right): \delta-0.07$ (s, $\left.3 \mathrm{H}, \mathrm{SiMe}\right), 0.00\left(\mathrm{~s}, 12 \mathrm{H}, \mathrm{SiMe} e_{2}\right), 0.38$ and $0.56\left(\mathrm{~m}, 14 \mathrm{H}, \mathrm{SiCH}_{2}\right), 1.31\left(\mathrm{~m}, 4 \mathrm{H}, \mathrm{SiCH}_{2} \mathrm{CH}_{2} \mathrm{CH}_{2} \mathrm{Si}\right), 1.62(\mathrm{~m}$, $6 \mathrm{H}, \mathrm{CH}_{2} \mathrm{CH}_{2} \mathrm{~N}^{+}$and $\left.\mathrm{ClCH}_{2} \mathrm{CH}_{2}\right), 3.05\left(\mathrm{~s}, 18 \mathrm{H},-\mathrm{NMe}_{3}{ }^{+}\right), 3.25\left(\mathrm{t}, \mathrm{J}_{\mathrm{a}}=\right.$ $\left.7.8 \mathrm{~Hz}, 4 \mathrm{H}, \mathrm{CH}_{2} \mathrm{~N}^{+}\right), 2.58\left(\mathrm{t}, \mathrm{J}_{\mathrm{b}}=6.5 \mathrm{~Hz}, \mathrm{ClCH}_{2}\right) .{ }^{13} \mathrm{C}\left\{{ }^{1} \mathrm{H}\right\} \mathrm{NMR}$ (DMSO$\left.\mathrm{d}_{6}\right): \delta-5.6(\mathrm{SiMe}),-3.9\left(\mathrm{SiMe}_{2}\right), 10.6\left(\mathrm{SiCH}_{2} \mathrm{CH}_{2} \mathrm{CH}_{2} \mathrm{~N}^{+}\right), 16.4-17.4$ $\left(\mathrm{SiCH}_{2} \mathrm{CH}_{2} \mathrm{CH}_{2} \mathrm{Si}\right), 18.6\left(\mathrm{CH}_{2} \mathrm{CH}_{2} \mathrm{~N}^{+}\right), 26.7\left(\mathrm{ClCH}_{2} \mathrm{CH}_{2}\right), 47.8\left(\mathrm{ClCH}_{2}\right)$, $51.6\left(-\mathrm{NMe}_{3}{ }^{+}\right), 67.4\left(\mathrm{SiCH}_{2} \mathrm{CH}_{2} \mathrm{CH}_{2} \mathrm{NMe}_{3}{ }^{+}\right) .{ }^{29} \mathrm{Si}-\mathrm{NMR}$ (DMSO-d 6 ): $\delta 2.1$ (SiMe), $2.4\left(\mathrm{SiMe}_{2}\right)$. ESI: (776.21 g/mol) q =1 (649.31 [M-I $\left.]^{+}\right)$. Anal. Calcd for $\mathrm{C}_{26} \mathrm{H}_{63} \mathrm{ClI}_{2} \mathrm{~N}_{2} \mathrm{Si}_{3}(777.31 \mathrm{~g} / \mathrm{mol})$ : C, 40.17; H, 8.17; N, 3.60; Exp.: C, 40.78; H, 8.39; N, 3.93 .

\section{$(\mathrm{PenV}) \mathrm{G}_{1}\left(\mathrm{Si}_{-\mathrm{NMe}} \mathrm{I}\right)_{2}(\mathrm{15})$}

To a solution of $14(0.050 \mathrm{~g}, 0.06 \mathrm{mmol})$ in dry DMF, PenVK $(0.027 \mathrm{~g}, 0.07 \mathrm{mmol})$ was added in the presence of ether crown 18C6 $(0.002 \mathrm{~g}, 0.01 \mathrm{mmol})$ and a catalytic amount of NaI. The mixture was heated at $80{ }^{\circ} \mathrm{C}$ in a sealed ampoule under argon atmosphere for $40 \mathrm{~h}$, after which volatiles were removed. After washing the residues with water, this dendron was obtained as a very hygroscopic white solid $(0.062 \mathrm{~g}, 89 \%)$.

$\left.{ }^{1} \mathrm{H} \mathrm{NMR}\left(\mathrm{CDCl}_{3}\right): \delta 0.00(\mathrm{~s}, 12 \mathrm{H}, \mathrm{SiMe})_{2}\right), 0.04(\mathrm{~s}, 3 \mathrm{H}, \mathrm{SiMe}), 0.57(\mathrm{~m}$, $\left.14 \mathrm{H}, \mathrm{SiCH}_{2}\right), 1.29\left(\mathrm{~m}, 4 \mathrm{H}, \mathrm{SiCH}_{2} \mathrm{CH}_{2} \mathrm{CH}_{2} \mathrm{Si}\right), 1.48$ (s, $\left.3 \mathrm{H}, \mathrm{CMe}_{2}\right), 1.58$ (s, $\left.3 \mathrm{H}, \mathrm{CMe}_{2}\right), 1.70\left(\mathrm{~m}, 6 \mathrm{H}, \mathrm{CH}_{2} \mathrm{CH}_{2} \mathrm{~N}^{+}\right.$and $\left.\mathrm{OCH}_{2} \mathrm{CH}_{2}\right), 3.41(\mathrm{~s}, 18 \mathrm{H}$, $\left.-\mathrm{NMe}_{3}{ }^{+}\right), 3.63\left(\mathrm{~m}, 4 \mathrm{H}, \mathrm{CH}_{2} \mathrm{~N}^{+}\right), 4.08\left(\mathrm{t}, \mathrm{J}_{\mathrm{a}}=8.4 \mathrm{~Hz}, 2 \mathrm{H},(\mathrm{CO}) \mathrm{OCH}_{2}\right)$, $4.43\left(\mathrm{~s}, 1 \mathrm{H}, \mathrm{CH}\left(\mathrm{CMe}_{2}\right)\right), 4.53\left(\mathrm{~s}, 2 \mathrm{H}, \mathrm{OCH}_{2} \mathrm{CO}\right), 5.56\left(\mathrm{~d}, J_{\mathrm{b}}=4.3 \mathrm{~Hz}\right.$, $1 \mathrm{H}, \mathrm{CHS}), 5.70(\mathrm{~m}, 1 \mathrm{H}, \mathrm{NHCH}), 6.90\left(\mathrm{~d}, \mathrm{~J}_{\mathrm{c}}=7.6 \mathrm{~Hz}, 2 \mathrm{H}, \mathrm{CH}_{\mathrm{Ar}}\right), 7.01$ (t, $\left.J_{\mathrm{d}}=7.4 \mathrm{~Hz}, 1 \mathrm{H}, \mathrm{CH}_{\mathrm{Ar}}\right), 7.30\left(\mathrm{~m}, 2 \mathrm{H}, \mathrm{CH}_{\mathrm{Ar}}\right) \cdot{ }^{13} \mathrm{C}\left\{{ }^{1} \mathrm{H}\right\} \mathrm{NMR}\left(\mathrm{CDCl}_{3}\right)$ : $\delta$-5.0 $\left(\mathrm{SiCH}_{3}\right),-3.2\left(\mathrm{SiMe}_{2}\right), 9.9\left(\mathrm{CH}_{2} \mathrm{Si}\right), 11.4\left(\mathrm{SiCH}_{2} \mathrm{CH}_{2} \mathrm{CH}_{2} \mathrm{~N}^{+}\right)$, 17.9, 18.0, and $18.3\left(\mathrm{SiCH}_{2} \mathrm{CH}_{2} \mathrm{CH}_{2} \mathrm{Si}\right), 19.8\left(\mathrm{CH}_{2} \mathrm{CH}_{2} \mathrm{~N}^{+}\right), 23.2\left(\mathrm{OCH}_{2} \mathrm{CH}_{2}\right)$, 26.8 and $32.0\left(\mathrm{SCMe}_{2}\right), 53.7\left(-\mathrm{NMe}_{3}{ }^{+}\right), 58.0(\mathrm{NHCH}), 64.7\left(\mathrm{SCMe}_{2}\right)$, $67.1\left(\mathrm{CH}_{2} \mathrm{~N}^{+}\right), 67.7\left(\mathrm{OCH}_{2} \mathrm{CO}\right), 68.4\left(\mathrm{COOCH}_{2}\right), 69.5(\mathrm{CHS}), 70.5(\mathrm{CH}-$ COO), $114.7\left(\mathrm{CH}_{\mathrm{Ar}}\right), 122.4\left(\mathrm{CH}_{\mathrm{Ar}}\right), 129.8\left(\mathrm{CH}_{\mathrm{Ar}}\right), 156.8\left(\mathrm{CO}_{\mathrm{Ar}}\right), 167.6$, 167.8, and $173.0(C=\mathrm{O})$. ESI: $(1090.32 \mathrm{~g} / \mathrm{mol}) \mathrm{q}=1\left(963.42[\mathrm{M}-\mathrm{I}]^{+}\right), \mathrm{q}=$ 2 (418.26 [M-2I] $\left.{ }^{2+}\right)$. Anal. Calcd for $\mathrm{C}_{42} \mathrm{H}_{80} \mathrm{I}_{2} \mathrm{~N}_{4} \mathrm{O}_{5} \mathrm{SSi}_{3}(1091.24 \mathrm{~g} / \mathrm{mol})$ : C, 46.23; H, 7.39; N, 5.13; Exp.: C, 45.94; H, 7.07; N, 4.43.

\section{DOSY NMR measurements}

DOSY experiments were carried out on a Bruker Advance 400 at $25{ }^{\circ} \mathrm{C}$. The values of midpoint between gradients $(\Delta)$ and gradient length ( $\delta$ ) were adjusted for free PenVK and for compound 14 in their solutions, and these values were later used in two different experiments for the mixture PenVK-14, not observing significant differences in the final result (Supplementary Fig. S6). 


\section{Pagination not final (cite DOI) / Pagination provisoire (citer le DOI)}

Fig. 1. Drawing of cationic dendrons of second generation $\left[\mathrm{XG}_{2}\left(\mathrm{Si}_{-}-\mathrm{NMe}_{3}\right)_{4}\right]^{4+}(\mathrm{X}=\mathrm{Cl},(\mathbf{1 4}) ; \mathrm{X}=\mathrm{PenV}(\mathbf{1 6}))$.

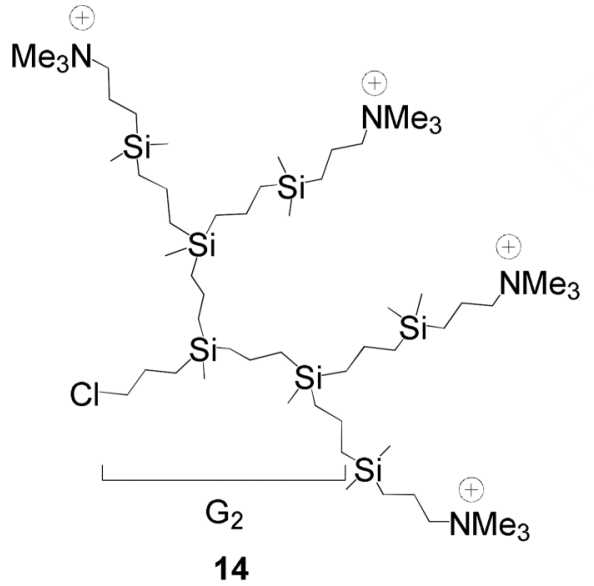

14

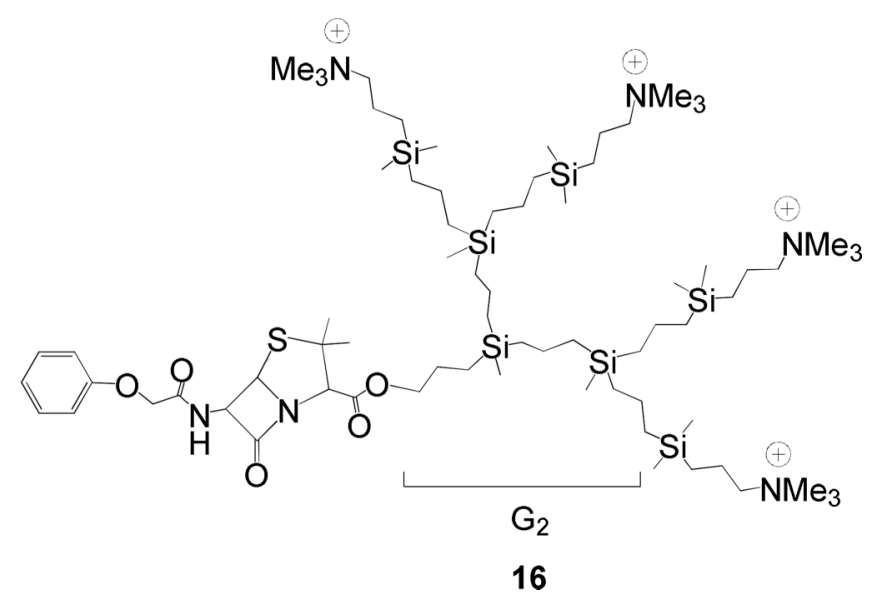

instability of the $\beta$-lactam ring toward the amino function, observing in the ${ }^{1} \mathrm{H}$ NMR spectra the disappearance of the original resonances belonging to this ring (data not shown). This instability of the $\beta$-lactam ring in the presence of $-\mathrm{NH}_{2}$ functions has been exploited for the preparation of benzylpenicilloyl-dendrimer conjugates to evaluate penicillin allergy. ${ }^{56}$

Alternatively, we proceeded to incorporate the PenV moiety to a vinyl dendron by direct reaction of the PenVK with the dendron containing a $\mathrm{Br}-\mathrm{C}$ bond at the focal point, $\mathrm{BrG}_{1} \mathrm{~V}_{2}$, in a similar way to other modifications introduced in these dendrons (Supplementary Scheme S1). ${ }^{52}$ Thus, after reaction treatment and purification, the corresponding dendron $(\operatorname{PenV}) G_{1} V_{2}(\mathbf{1})$ was obtained as a yellowish oil in good yield. The main NMR data that confirmed this transformation were the resonances corresponding to the $\mathrm{CH}_{2}$ moiety of the new ester bond, observed at $\delta 4.16^{1} \mathrm{H}$ NMR spectrum and at $\delta 65.4{ }^{13} \mathrm{C}$ NMR spectrum, respectively.

Unfortunately, subsequent modification of the periphery of 1 via thiol-ene addition failed, leading again to the rupture of the $\beta$-lactam ring, probably caused by a nucleophilic attack of the thiol function to the carbonyl carbon of this ring (Scheme 1). ${ }^{57}$ Nevertheless, the halogen-PenV exchange seemed to be a promising procedure to obtain dendrons with a PenV unit at the focal point. Hence, we designed a cationic dendron with a $\mathrm{Cl}-\mathrm{C}$ bond at the focal point and cationic peripheral functions at the periphery. The reason for the presence of a $\mathrm{Cl}-\mathrm{C}$ bond instead of a $\mathrm{Br}-\mathrm{C}$ bond is the clearly enhanced reactivity of the latter towards amines.

For the synthesis of this new dendron (Supplementary Scheme S2), we started from $\mathrm{ClG}_{1} \mathrm{~V}_{2}{ }^{53}$ and carried out a thiol-ene addition with cysteamine hydrochloride $\left(\mathrm{HS}\left(\mathrm{CH}_{2}\right)_{2} \mathrm{NMe}_{2} \cdot \mathrm{HCl}\right)$ under UV irradiation, obtaining $\left[\mathrm{ClG}_{1}\left(\mathrm{~S}-\mathrm{NMe}_{2} \mathrm{H}\right)_{2}\right]^{2+}(\mathbf{2})$ as a white solid. The formation of this compound was confirmed by NMR spectroscopy: the resonances of the vinyl groups disappeared in both ${ }^{1} \mathrm{H}$ NMR and ${ }^{13} \mathrm{C}$ NMR spectra; the new chain formed $\mathrm{Si}\left(\mathrm{CH}_{2}\right)_{2} \mathrm{~S}$ presented in the ${ }^{1} \mathrm{H}$ NMR two multiplets at $\delta 0.87\left(\mathrm{SiCH}_{2}\right)$ and at $2.60\left(\mathrm{CH}_{2} \mathrm{~S}\right)$ and in the ${ }^{13} \mathrm{C}$ NMR two signals at $\delta 13.5\left(\mathrm{SiCH}_{2}\right)$ and at $26.0\left(\mathrm{CH}_{2} \mathrm{~S}\right)$; and the resonances of the new chain introduced $\mathrm{S}\left(\mathrm{CH}_{2}\right)_{2} \mathrm{NMe}_{2} \mathrm{H}$ were also observed. Next, basic treatment of 2 led to the neutral dendron $\mathrm{ClG}_{1}\left(\mathrm{~S}-\mathrm{NMe}_{2}\right)(3)$ that was obtained as a yellowish oil. The ${ }^{1} \mathrm{H}$ NMR spectrum showed a clear shifting of the $\mathrm{NMe}_{2}$ groups from $\delta$ 2.73 in 2 to $\delta 2.24$ in 3 . Finally, addition of MeI to 3 afforded the cationic dendron $\left[\mathrm{ClG}_{1}\left(\mathrm{~S}-\mathrm{NMe}_{3}\right)_{2}\right]^{2+}(4)$, which was isolated as a pale yellow solid. In this case, the resonances of the $\mathrm{Me}_{3} \mathrm{~N}^{+}$groups were shifted to higher frequency, being observed in the ${ }^{1} \mathrm{H}$ NMR spectrum at $\delta 3.07$.

Again, the reaction of dendron $\left[\mathrm{ClG}_{1}\left(\mathrm{~S}-\mathrm{NMe}_{3}\right)_{2}\right]^{2+}(4)$ with PenVK (Scheme 1) did not render the desired dendron, once again observing the rupture of the $\beta$-lactam ring by means of modification

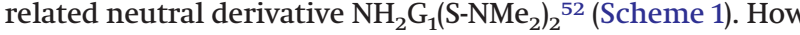
the reaction of neutral PenV with these dendrons failed due to 
Scheme 1. Failed attempts to obtained penicillin (PenV) functionalized dendrons containing sulfur atoms.

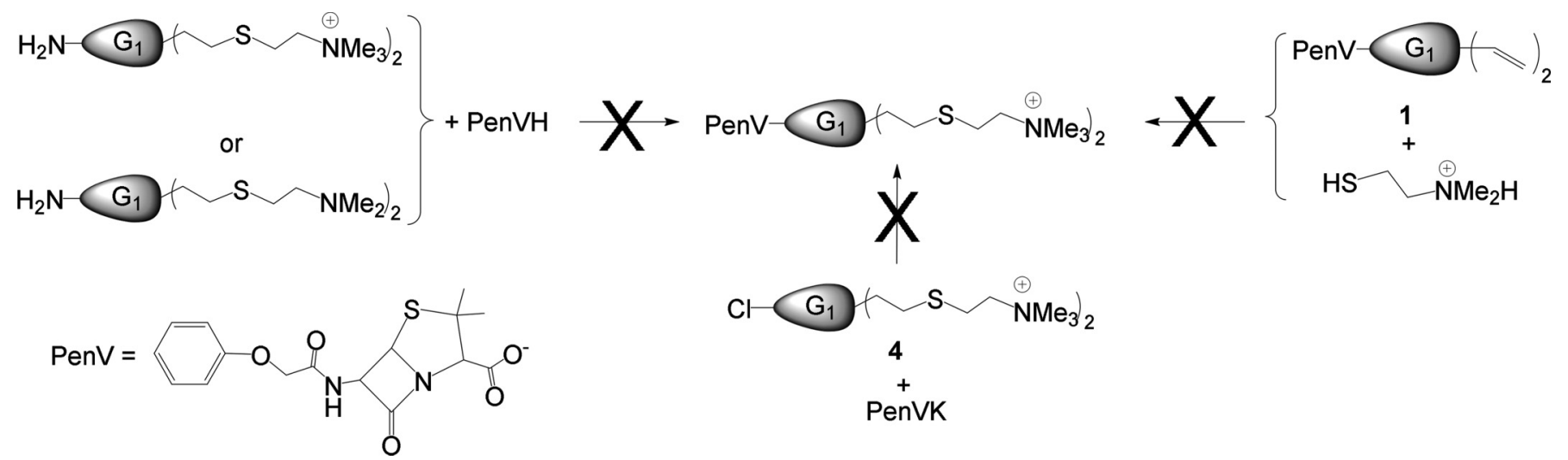

Scheme 2. Synthesis of carbosilane dendrons containing peripheral $\mathrm{Si}-\mathrm{H}$ bonds and a $\mathrm{Cl}-\mathrm{C}$ bond at the focal point $\mathrm{ClG}{ }_{n}(\mathrm{SiH})_{m}(n=1, m=2(6)$; $n=2, m=4$ (10)). (i) $\mathrm{HSiMe}_{2} \mathrm{Cl}, 60{ }^{\circ} \mathrm{C}$, [Pt], $4 \mathrm{~h}$; (ii) $\mathrm{LiAlH}_{4}, \mathrm{Et}_{2} \mathrm{O}, 0{ }^{\circ} \mathrm{C}$ to room temperature, $16 \mathrm{~h}$; (iii) $\mathrm{HSiMeCl}_{2}, 60^{\circ} \mathrm{C},[\mathrm{Pt}], 4 \mathrm{~h}$; (iv) $\mathrm{BrMg}(\mathrm{allyl})$, $\mathrm{Et}_{2} \mathrm{O}, 0{ }^{\circ} \mathrm{C}$ to room temperature, $16 \mathrm{~h}$.

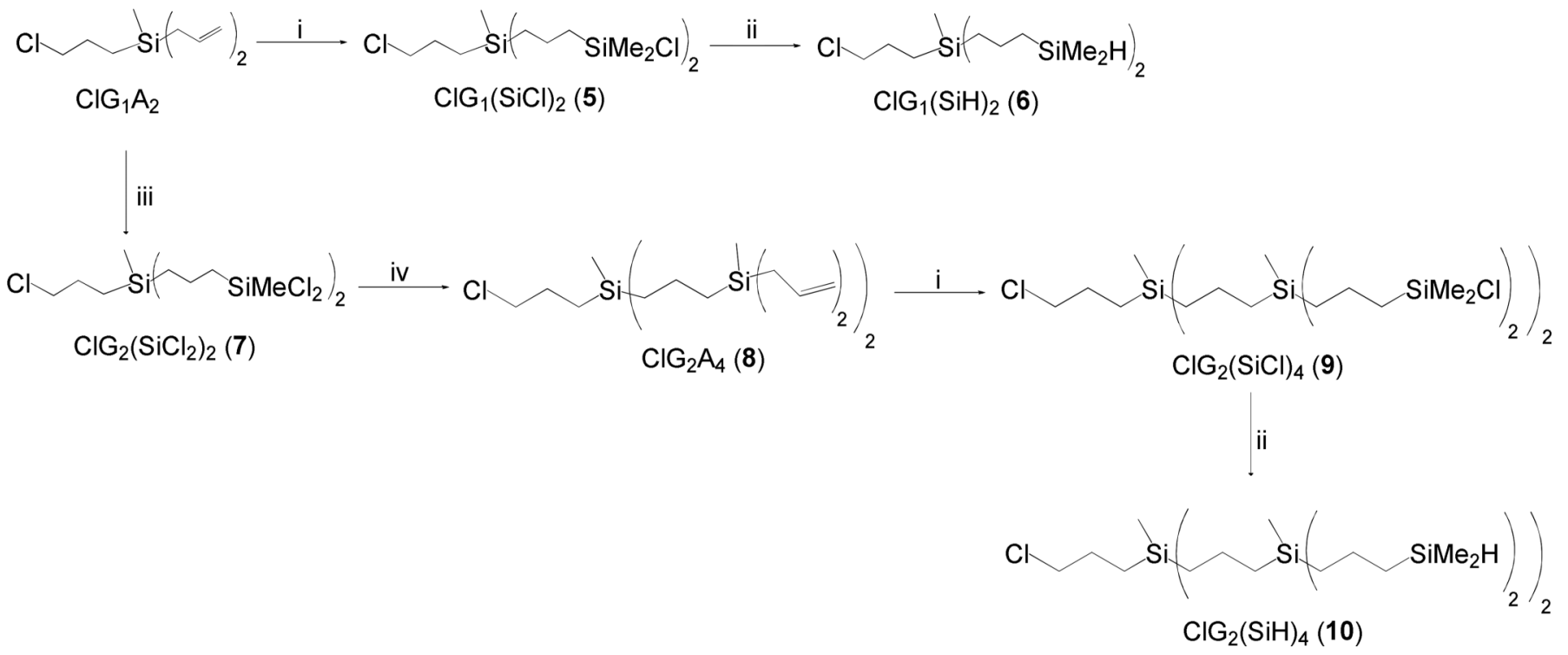

of their resonances in the ${ }^{1} \mathrm{H}$ NMR spectrum. In this case, this $\beta$-lactam ring probably suffered a nucleophilic attack of the thioether function. It is important to note that this reaction requires heating over $80^{\circ} \mathrm{C}$.

To bypass all these drawbacks in the synthesis of a cationic carbosilane dendron containing a PenV moiety, we moved to modification of the dendron surface by hydrosilylation processes instead of thiol-ene addition, with the aim to avoid the presence of any donor atom in the final dendron. This methodology successfully allowed us to prepare cationic dendrons with PenV at the focal point.

Thus, starting from $\mathrm{ClG}_{1} \mathrm{~A}_{2}{ }^{54}$ and using typical reactions for the preparation of carbosilane dendritic systems (hydrosilylation, alkenylation, and $\mathrm{Cl}-\mathrm{H}$ substitution; Scheme 2), ${ }^{58}$ we obtained dendrons with a $\mathrm{Cl}-\mathrm{C}$ bond at the focal point and $\mathrm{Si}-\mathrm{H}$ peripheral groups $\mathrm{ClG}_{n}(\mathrm{SiH})_{m}(n=1, m=2(6) ; n=2, m=4(\mathbf{1 0}))$. Treatment of these derivatives with allyldimethylamine in the presence of Karstedt's catalyst ${ }^{59}$ afforded the neutral dendrons $\mathrm{ClG}_{n}\left(\mathrm{Si}_{-}-\mathrm{NMe}_{2}\right)_{m}$ ( $n=1, m=2$ (11); $n=2, m=4$ (12) (Scheme 3). NMR spectroscopy clearly showed the incorporation of the new propylene chain $\left(\mathrm{Si}\left(\mathrm{CH}_{2}\right)_{3} \mathrm{~N}\right)$ to the dendrimer structure by means of the resonances in the ${ }^{1} \mathrm{H}$ NMR spectra at $\delta$ ca. $0.44\left(\mathrm{SiCH}_{2}\right), 1.40\left(\mathrm{CH}_{2}\right)$, and 2.20 $\left(\mathrm{CH}_{2} \mathrm{~N}\right)$ and in the ${ }^{13} \mathrm{C}$ NMR spectra at $\delta$ ca. $12.8\left(\mathrm{SiCH}_{2}\right), 22.1\left(\mathrm{CH}_{2}\right)$, and $63.4\left(\mathrm{CH}_{2} \mathrm{~N}\right)$. These compounds were easily transformed into the cationic ones $\left[\mathrm{ClG}_{n}\left(\mathrm{Si}_{\mathrm{NMe}}\right)_{m}\right]^{m+}(n=1, m=2(\mathbf{1 3}) ; n=2, m=4$ (14) by addition of MeI (Scheme 3; Fig. 1). The typical shifting to higher frequency of the methyl $(\mathrm{MeN})$ resonances was observed in the ${ }^{1} \mathrm{H}$ NMR spectra (Supplementary Figs. S1 and S2). Subsequent heating of 13 and 14 with PenVK yielded the goal dendrons

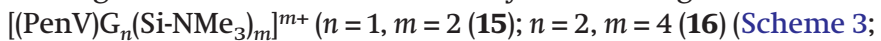
Fig. 1), which were isolated in good yields as highly hygroscopic pale yellow solids. The solubility was generation dependent, being G1 dendron soluble in chlorinated solvents, alcohols, and DMSO but not in water, whereas G2 dendron was soluble in water and other highly polar solvents but not in chlorinated solvents. NMR (Figs. 2 and 3), MS (Supplementary Fig. S3), and elemental analysis were in accordance with this formulation. The main NMR data confirming formation of these dendrons were the resonances associated to the ester fragment. The $\mathrm{CH}_{2} \mathrm{O}$ group was observed at about $\delta 4.1$ and $\delta 67$ in the ${ }^{1} \mathrm{H}$ and ${ }^{13} \mathrm{C}$ spectra, respectively, and the corresponding carbon atom of the carbonyl group at about $\delta 173$ in the ${ }^{13} \mathrm{C}$ spectra. Furthermore, the binding of PenV to the dendron was confirmed by DOSY NMR, showing the joint diffusion of both moieties (Supplementary Fig. S3), in comparison with the mixture of PenV and dendron 14 (Supplementary Fig. S6). The formation and stability of the dendrons containing the PenV moi- 
Scheme 3. Synthesis of dendrons $\left[(\mathrm{PenV}) \mathrm{G}_{n}\left(\mathrm{Si}_{-} \mathrm{NMe}_{3}\right)_{m}\right]^{m+}(n=1, m=2(\mathbf{1 5}) ; n=2, m=4(\mathbf{1 6}))$ with PenV at the focal point and cationic peripheral groups derived by hydrosilylation. (i) (allyl) $\mathrm{NMe}_{2}, 60^{\circ} \mathrm{C}$, [Pt]; (ii) MeI, THF, room temperature, 16 h; (iii) PenVK, ether crown $18 \mathrm{C} 6$, NaI, DMF, $80^{\circ} \mathrm{C}, 40 \mathrm{~h}$.

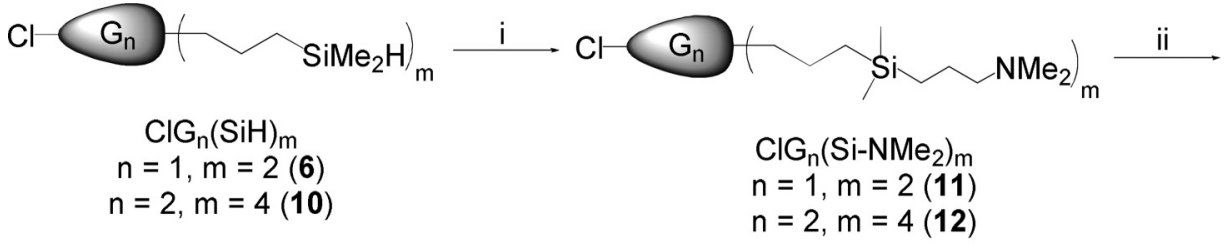

$$
\begin{aligned}
& \mathrm{ClG}_{\mathrm{n}}\left(\mathrm{Si}-\mathrm{NMe}_{2}\right)_{\mathrm{m}} \\
& \mathrm{n}=1, \mathrm{~m}=2(\mathbf{1 1}) \\
& \mathrm{n}=2, \mathrm{~m}=4(\mathbf{1 2})
\end{aligned}
$$
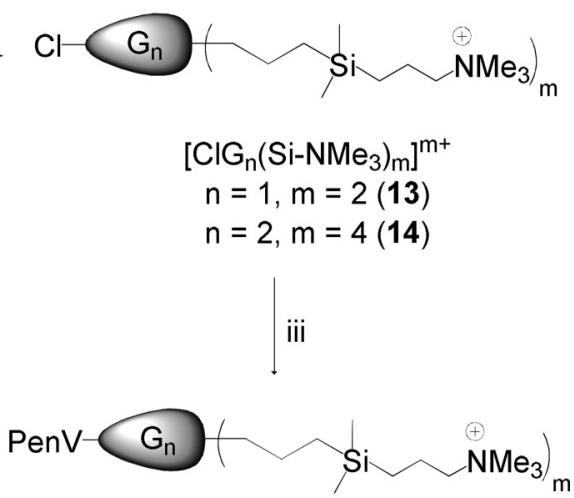

$\left[(\text { PenV }) G_{n}\left(\mathrm{Si}_{-N M e_{3}}\right)_{m}\right]^{\mathrm{m}+}$
$n=1, m=2(\mathbf{1 5})$
$n=2, m=4(\mathbf{1 6})$

Fig. 2. ${ }^{1} \mathrm{H}$ NMR of $\left[(\mathrm{PenV}) \mathrm{G}_{2}\left(\mathrm{Si}^{-} \mathrm{NMe}_{3}\right)_{4}\right]^{4+}(\mathbf{1 6})$ in DMSO-D6.

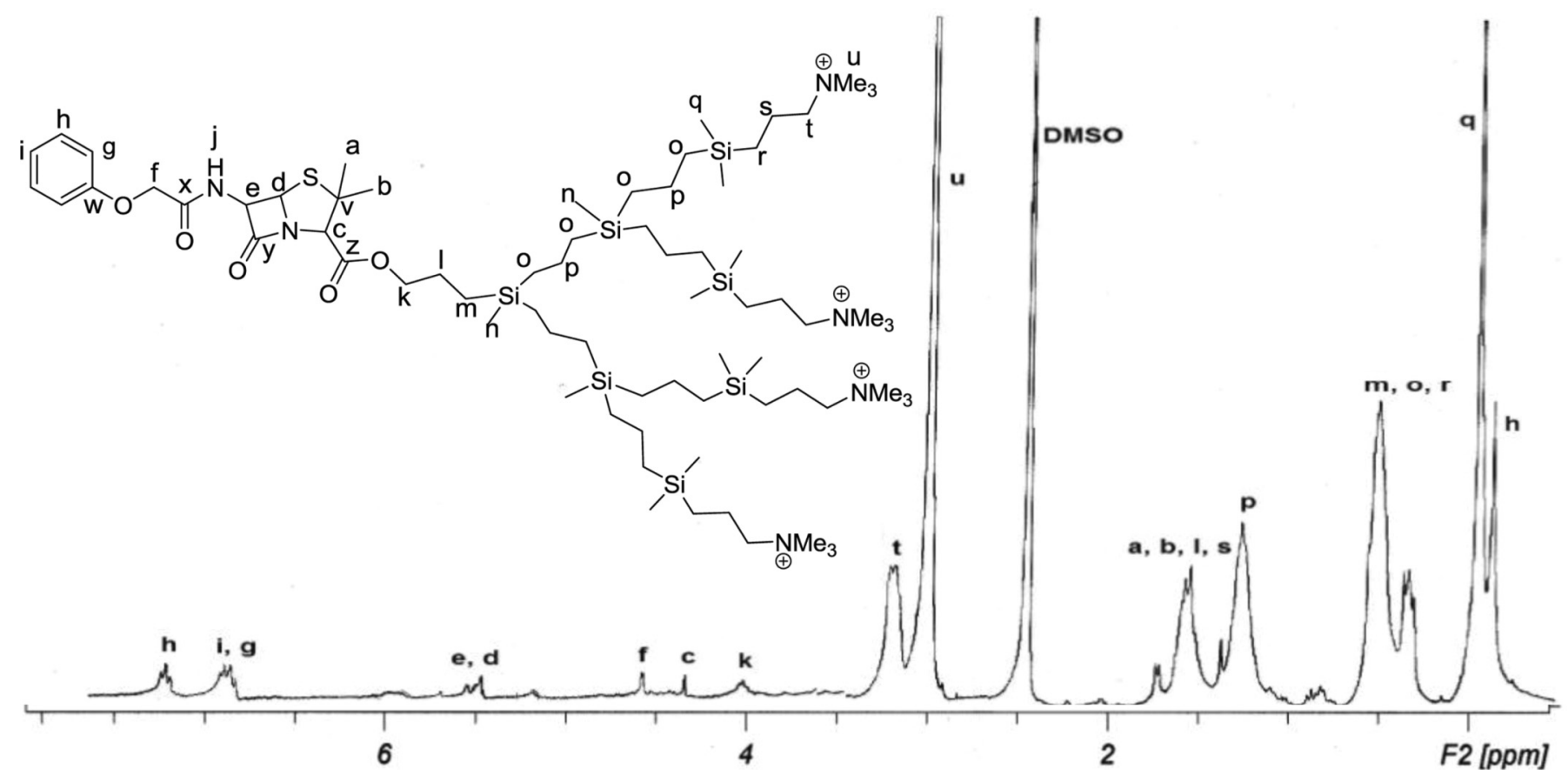

ety 14 and 16 following this route confirms that the presence of donor atoms such as $\mathrm{S}$ or $\mathrm{N}$ in the dendron structure was responsible of $\beta$-lactam ring degradation.

\section{Antibacterial activity}

For the study of the biocidal capacity of dendrons, S. aureus was chosen as a model of gram-positive bacteria, as penicillin is a specific antibiotic for this type of bacteria. Figure 1 depicts drawings of cationic dendrons employed for the assays. To ascertain the effect of the PenV moiety in dendron $\left[(\mathrm{PenV}) \mathrm{G}_{2}\left(\mathrm{Si}-\mathrm{NMe}_{3}\right)_{4}\right]^{4+}$ (16), a comparative study of the antibacterial activity of this dendron with its parent compound $\left[\mathrm{ClG}_{2}\left(\mathrm{Si}-\mathrm{NMe}_{3}\right)_{4}\right]^{4+}(\mathbf{1 4})$ and an equimolecular mixture of PenVK salt plus dendron 14 was carried out. Table 1 summarizes the MIC and MBC of these dendrons.
The data obtained point out the following facts: (i) there were slight differences in the antibacterial response of dendrons with or without PenV at the focal point $\left[\mathrm{ClG}_{2}\left(\mathrm{Si}-\mathrm{NMe}_{3}\right)_{4}\right]^{4+}(\mathbf{1 4})$ and $\left[(\mathrm{PenV}) \mathrm{G}_{2}\left(\mathrm{Si}_{-} \mathrm{NMe}_{3}\right)_{4}\right]^{4+}(\mathbf{1 6})$; (ii) there was much lower activity of the PenV fragment in $\mathbf{1 6}$ than that of the free PenV; and (iii) a MIC for the stoichiometric mixture of PenVK and 14 was similar to that obtained for free PenVK, whereas the MBC increased to $0.78 \mathrm{ppm}$ (with respect to PenV), which was much higher than that of free PenVK.

The decrease of the bactericide activity (MBC) of the mixture PenVK-14 compared with free PenVK could be explained in terms of availability of the antibiotic, because PenV is an anionic compound capable of interacting with the cationic dendron ${ }^{50}$ and, thus, likely to diminish its availability. Comparison of the diffusion coefficients of free PenVK and PenVK in an equimolecular 
Fig. 3. ${ }^{13} \mathrm{C}$ NMR of $\left[(\mathrm{PenV}) \mathrm{G}_{2}\left(\mathrm{Si}_{-}-\mathrm{NMe}_{3}\right)_{4}\right]^{4+}(\mathbf{1 6})$ in DMSO-D6.

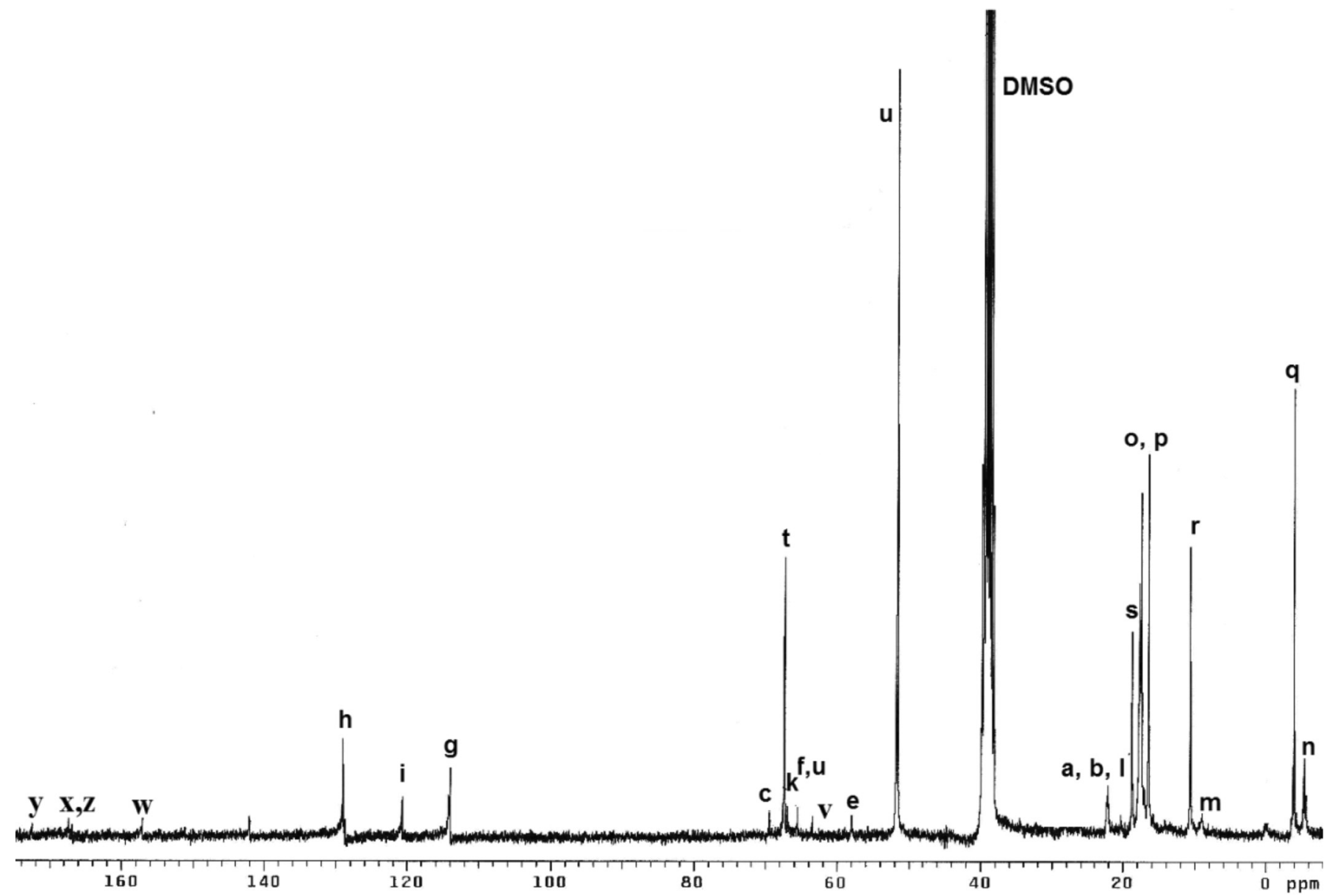

Table 1. Antibacterial activity of PenV, dendrons $\left[\mathrm{XG}_{2}\left(\mathrm{Si}-\mathrm{NMe}_{3}\right)_{4}\right]^{4+}(\mathrm{X}=\mathrm{Cl}, 14 ; \mathrm{PenV}, 16)$, and equimolecular mixture of PenVK and 14 against S. aureus.

\begin{tabular}{llllll}
\hline & \multicolumn{2}{l}{$\mathrm{MIC}$} & & & \multicolumn{2}{l}{$\mathrm{MBC}$} & \\
\cline { 2 - 3 } \cline { 6 - 6 } & $\mathrm{ppm}$ & {$\left[\mathrm{NR}_{3}{ }^{+}\right]$} & & $\mathrm{ppm}$ & {$\left[\mathrm{NR}_{3}{ }^{+}\right]$} \\
\hline PenVK & 0.016 & - & & 0.031 & - \\
$\mathbf{1 4}$ & 8 & 20 & & 8 & 20 \\
PenVK-14 & $0.012^{a}$ & 0.14 & & $0.78^{a}$ & 9 \\
$\mathbf{1 6}$ & $2.91^{a}$ & 33 & & $2.91^{a}$ & 33 \\
$\mathbf{1 6 - e s t e r e a s e}$ & $0.95^{a}$ & 3.70 & & $0.95^{a}$ & 3.70 \\
\hline
\end{tabular}

Note: $\left[\mathrm{NR}_{3}{ }^{+}\right]$refers to the $\mu \mathrm{mol} / \mathrm{L}$ concentration of ammonium groups.

${ }^{a}$ refers to ppm concentration of PenV.

mixture with dendron $\left[\mathrm{ClG}_{2}\left(\mathrm{Si}_{-} \mathrm{NMe}_{3}\right)_{4}\right]^{4+}(\mathbf{1 4})$ by DOSY 2D NMR experiments showed that this coefficient is clearly smaller when the dendron is present. This means that diffusion of PenVK is affected by the dendron, supporting the assessment of interaction between both systems (Supplementary Fig. S6). Although in our case the dendron-PenV interaction seems to difficult the action of the antibiotic, it has been reported that electrostatic interaction between $\beta$-lactam antibiotics and a polymer containing cationic cobaltocenium units exhibit synergistic effects against methicillin resistant $S$. aureus by efficiently inhibiting activity of $\beta$-lactamase and effectively lysing bacterial cells. ${ }^{60}$

In the case of dendron $\left[(\mathrm{PenV}) \mathrm{G}_{2}\left(\mathrm{Si}_{-}-\mathrm{NMe}_{3}\right)_{4}\right]^{4+}(\mathbf{1 6})$ with a covalently bonded PenV, the higher inhibitory and bactericidal concentration values with respect to free PenVK are probably due to the fact that the ester bond is not adequately split in solution. The activity of PenV requires the availability of the carboxylate moiety, which also favours its stability, as the formation of the ester bond to conjugate penicillin to the dendron alters the crucial equilibrium between stability and activity of the $\beta$-lactam ring. ${ }^{61}$ Thus, the presence of this ester bond triggers the reactivity of the ring, thereby affecting their activity.

With the aim of facilitating the release of the penicillin fragment by rupture of the ester bond, we tested the antibacterial activity of dendron $\left[(\mathrm{PenV}) \mathrm{G}_{2}\left(\mathrm{Si}_{\mathrm{NMe}}\right)_{4}\right]^{4+}(\mathbf{1 6})$ in the presence of porcine liver esterase. For this experiment, we initially added one unit of esterase per ester bond. From the first moment, the activity increased $(\mathrm{MIC}=0.95 \mathrm{ppm}$ and $\mathrm{MBC}=0.95 \mathrm{ppm}$, with respect to the concentration of PenV), confirming the splitting of the ester bond. However, the obtained values were different from those for free PenV in the absence of dendron. This may be due to the electrostatic interactions of free PenV with the dendron or also to partial degradation of penicillin previous to its release from dendron. Addition of excess esterase did not affect the behavior observed in this experiment.

\section{Conclusions}

Carbosilane cationic dendrons with a penicillin moiety at the focal point can be obtained, employing the carboxylate group of penicillin (PenV) to be attached to the dendron. However, the synthetic protocol requires avoiding the presence of donor atoms or groups to avoid degradation of the $\beta$-lactam ring, which is responsible for the penicillin activity.

Evaluation of the activity of this dendron (16) and of a mixture of cationic dendron (14) and free PenV revealed that both covalent 
conjugation of PenV to the dendron or electrostatic interaction between PenV and the cationic dendron reduced penicillin activity. These phenomena can be ascribed to the blocking of the carboxylate group of penicillin, which also favours the hydrolysis of the $\beta$-lactam ring. Hydrolysis of the ester bond in dendron 16 with an esterease increases the activity, without reaching the values of free penicillin. However, the release of penicillin in this system could be useful to apply similar compounds in drug release of drugs where the carboxylate unit does not play a key role in its therapeutic action.

\section{Supplementary data}

Supplementary data, including complete experimental procedures and selected NMR spectra, are available with the article through the journal Web site at http://nrcresearchpress.com/doi/ suppl/10.1139/cjc-2017-0059.

\section{Acknowledgements}

This work was supported by grants from CTQ-2014-54004-P (MINECO) to University of Alcalá, as well as grants from the Ministerio de Educación to E.F.P. (AP2010-1470). CIBER-BBN is an initiative funded by the VI National R\&D\&I Plan 2008-2011, Iniciativa Ingenio 2010, Consolider Program, and CIBER Actions and financed by the Instituto de Salud Carlos III with assistance from the European Regional Development Fund.

\section{References}

(1) Lode, H. M. Clin. Microbiol. Infect. 2009, 15, 212. doi:10.1111/j.1469-0691.2009. 02738.x.

(2) Gonzales, F. P.; Maisch, T. Drug News Perspect. 2010, 23, 167. doi:10.1358/dnp. 2010.23.3.1444225.

(3) Blair, J. M. A.; Webber, M. A.; Baylay, A. J.; Ogbolu, D. O.; Piddock, L. J. Nat. Rev. Microbiol. 2015, 13, 42. doi:10.1038/nrmicro3380.

(4) Antimicrobial Resistance: Global Report on Surveillance [online]; World Health Organization: Geneva, 2014. http://apps.who.int/iris/bitstream/10665/ 112642/1/9789241564748_eng.pdf.

(5) Donlan, R. M. Emerg. Infect. Dis. 2002, 8, 881. doi:10.3201/eid0809.020063.

(6) Bryers, J. D. In Microbial Biofilms: Current Research and Applications; Lear, G., Lewis, G. D., Eds.; Caister Academic Press: Poole, UK, 2012; pp. 25-42.

(7) Muñoz-Bonilla, A.; Fernández-García, M. Prog. Polym. Sci. 2012, 37, 281. doi: 10.1016/j.progpolymsci.2011.08.005.

(8) Coates, A.; Hu, Y.; Bax, R.; Page, C. Nat. Rev. Drug Discovery 2002, 1, 895. doi:10.1038/nrd940.

(9) Clifton, L. A.; Skoda, M. W. A.; Le Brun, A. P.; Ciesielski, F.; Kuzmenko, I.; Holt, S. A.; Lakey, J. H. Langmuir 2015, 31, 404. doi:10.1021/la504407y.

(10) Tischer, M.; Pradel, G.; Ohlsen, K.; Holzgrabe, U. ChemMedChem 2012, 7, 22. doi:10.1002/cmdc.201100404.

(11) Panarin, E. F.; Solovskii, M. V.; Zaikina, N. A.; Afinogenov, G. E. Makromol. Chem., Suppl. 1985, 9, 25. doi:10.1002/macp.1985.020091985104.

(12) Tompkin, R. B. Food Technol. 1984, 38, 226.

(13) Dizman, B.; Elasri, M. O.; Mathias, L. J. J. Appl. Polym. Sci. 2004, 94, 635. doi:10.1002/app.20872.

(14) Osamura, T.; Ozawa, M.; Iwama, T. Patent JP2011037716A, 2011.

(15) Mintzer, M. A.; Dane, E. L.; O’Toole, G. A.; Grinstaff, M. W. Mol. Pharmaceutics 2012, 9, 342. doi:10.1021/mp2005033.

(16) Lazniewska, J.; Milowska, K.; Gabryelak, T. WIREs Nanomed. Nanobiotechnol. 2012, 4, 469. doi:10.1002/wnan.1181.

(17) Ikeda, T.; Hirayama, H.; Yamaguchi, H.; Tazuke, S.; Watanabe, M. Antimicrob. Agents Chemother. 1986, 30, 132. doi:10.1128/AAC.30.1.132.

(18) Newkome, G. R.; Shreiner, C. D. Polymer 2008, 49, 1. doi:10.1016/j.polymer. 2007.10.021.

(19) Tomalia, D. A.; Fréchet, J. M. J. J. Polym. Sci., Part A: Polym. Chem. 2002, 40, 2719. doi:10.1002/pola.10301.

(20) Fréchet, J. M. J.; Tomalia, D. A. Dendrimers and Other Dendritic Polymers; WileyVCH: Weinheim, 2002. doi:10.1002/0470845821.

(21) Wang, B.; Navath, R. S.; Menjoge, A. R.; Balakrishnan, B.; Bellair, R.; Dai, H.; Romero, R.; Kannan, S.; Kannan, R. M. Int. J. Pharm. 2010, 395, 298. doi:10. 1016/j.ijpharm.2010.05.030.

(22) Chen, C. Z.; Beck-Tan, N. C.; Dhurjati, P.; van Dyk, T. K.; LaRossa, R. A.; Cooper, S. L. Biomacromolecules 2000, 1, 473. doi:10.1021/bm0055495.

(23) Ciepluch, K.; Katir, N.; El Kadib, A.; Felczak, A.; Zawadzka, K.; Weber, M.; Klajnert, B.; Lisowska, K.; Caminade, A.-M.; Bousmina, M.; Bryszewska, M.; Majoral, J. P. Mol. Pharmaceutics 2012, 9, 448. doi:10.1021/mp200549c.

(24) Rasines, B.; Hernández-Ros, J. M.; de las Cuevas, N.; Copa-Patiño, J. L.; Soliveri, J.; Muñoz-Fernández, M. A.; Gómez, R.; de la Mata, F. J. Dalton Trans. 2009, 8704. doi:10.1039/B909955G.
(25) Tulu, M.; Aghatabay, N. M.; Senel, M.; Dizman, C.; Parali, T.; Dulger, B. Eur. J. Med. Chem. 2009, 44, 1093. doi:10.1016/j.ejmech.2008.06.016.

(26) Chen, C. Z.; Cooper, S. L. Biomaterials 2002, 23, 3359. doi:10.1016/S01429612(02)00036-4.

(27) Janiszewska, J.; Sowińska, M.; Rajnisz, A.; Solecka, J.; Łącka, I.; Milewski, S.; Urbańczyk-Lipkowska, Z. Bioorg. Med. Chem. Lett. 2012, 22, 1388. doi:10.1016/ j.bmcl.2011.12.051.

(28) Ghosh, S.; Banthia, A. K. J. Biomed. Mater. Res., Part A 2004, 71A, 1. doi:10.1002/ jbm.a.30121.

(29) Moussodia, R.-O.; Balan, L.; Merlin, C.; Mustin, C.; Schneider, R. J. Mater. Chem. 2010, 20, 1147. doi:10.1039/B917629B.

(30) Öberg, K.; Ropponen, J.; Kelly, J.; Löwenhielm, P.; Berglin, M.; Malkoch, M. Langmuir 2013, 29, 456. doi:10.1021/la3041314.

(31) Kesharwani, P.; Jain, K.; Jain, N. K. Prog. Polym. Sci. 2014, 39, 268. doi:10.1016/ j.progpolymsci.2013.07.005.

(32) Gillies, E. R.; Fréchet, J. M. J. Drug Discovery Today 2005, 10, 35. doi:10.1016/ S1359-6446(04)03276-3.

(33) Sonawane, S. J.; Kalhapure, R. S.; Rambharose, S.; Mocktar, C.; Vepuri, S. B.; Soliman, M.; Govender, T. Int. J. Pharm. 2016, 504, 1. doi:10.1016/j.ijpharm. 2016.03.021.

(34) Wrońska, N.; Felczak, A. Zawadzka, K.; Poszepczyńska, M.; Różalska, S; Bryszewska, M.; Appelhans, D.; Lisowska, K. Molecules 2015, 20, 19330. doi: 10.3390/molecules201019330.

(35) Aghayari, M.; Salouti, M.; Kazemizadeh, A. R.; Zabihian, A.; Hamidi, M.; Shajari, N.; Moghtader, F. Sci. Iran. 2015, 22, 1330.

(36) Winnicka, K.; Wroblewska, M.; Wieczorek, P.; Sacha, P. T.; Tryniszewska, E. A. Molecules 2013, 18, 8607. doi:10.3390/molecules18078607.

(37) Felczak, A.; Zawadzka, K.; Wrońska, N.; Janaszewska, A.; Klajnert, B.; Bryszewska, M.; Appelhans, D.; Voit, B.; Lisowska, K. New J. Chem. 2013, 37, 4156. doi:10.1039/c3nj00760j.

(38) Ngu-Schwemlein, M.; Chin, S. F.; Hileman, R.; Drozdowski, C.; Upchurch, C.; Hargrove, A. Bioorg. Med. Chem. Lett. 2016, 26, 1745. doi:10.1016/j.bmcl.2016. 02.047 .

(39) Michaud, G.; Visini, R.; Bergmann, M.; Salerno, G.; Bosco, R.; Gillon, E.; Richichi, B.; Nativi, C.; Imberty, A.; Stocker, A.; Darbre, T.; Reymond, J. L. Chem. Sci. 2016, 7, 166. doi:10.1039/C5SC03635F.

(40) Zhou, Y.-J.; Zhang, M.-X.; Hider, R. C.; Zhou, T. FEMS Microbiol. Lett. 2014, 355, 124. doi:10.1111/1574-6968.12465.

(41) van der Made, A. W.; van Leeuwen, P. W. N. M.; de Wilde, J. C.; Brandes, R. A. C. Adv. Mater. 1993, 5, 466. doi:10.1002/adma.19930050613.

(42) van der Made, A. W.; van Leeuwen, P. W. N. M. J. Chem. Soc., Chem. Commun. 1992, 1400. doi:10.1039/C39920001400.

(43) Ortega, P.; Cobaleda, B. M.; Hernández-Ros, J. M.; Fuentes-Paniagua, E.; Sánchez-Nieves, J.; Tarazona, M. P.; Copa-Patiño, J. L.; Soliveri, J.; de la Mata, F. J.; Gómez, R. Org. Biomol. Chem. 2011, 9, 5238. doi:10.1039/ c1ob05321c.

(44) Fuentes-Paniagua, E.; Hernández-Ros, J. M.; Sánchez-Milla, M.; Camero, M. A.; Maly, M.; Pérez-Serrano, J.; Copa-Patiño, J. L.; Sánchez-Nieves, J.; Soliveri, J.; Gómez, R.; de la Mata, F. J. RSC Adv. 2014, 4, 1256. doi:10.1039/C3RA45408H.

(45) Heredero-Bermejo, I.; Copa-Patiño, J. L.; Soliveri, J.; Fuentes-Paniagua, E.; de la Mata, F. J.; Gómez, R.; Pérez-Serrano, J. Parasitol. Res. 2015, 114, 473. doi:10.1007/s00436-014-4205-1.

(46) Heredero-Bermejo, I.; Copa-Patiño, J. L.; Soliveri, J.; García-Gallego, S ; Rasines, B.; Gómez, R.; de la Mata, F. J.; Pérez-Serrano, J. Parasitol. Res. 2013, 112, 961. doi:10.1007/s00436-012-3216-Z.

(47) Fuentes-Paniagua, E.; Sánchez-Nieves, J.; Hernández-Ros, J. M.; Fernández-Ezequiel, A.; Soliveri, J.; Copa-Patiño, J. L.; Gómez, R.; de la Mata, F. J. RSC Adv. 2016, 6, 7022. doi:10.1039/C5RA25901K.

(48) Heredero-Bermejo, I.; Sánchez-Nieves, J.; Soliveri, J.; Gómez, R.; de la Mata, F. J.; Copa-Patiño, J. L.; Pérez-Serrano, J. Int. J. Pharm. 2016, 509, 1. doi:10.1016/j.ijpharm.2016.04.075.

(49) Cottarel, G.; Wierzbowski, J. Trends Biotechnol. 2007, 25, 547. doi:10.1016/j. tibtech.2007.09.004

(50) Rasines, B.; Sánchez-Nieves, J.; Molina, I. T.; Guzmán, M.; Muñoz-Fernández, M. Á.; Gómez, R.; de la Mata, F. J. New J. Chem. 2012, 36, 360. doi:10.1039/C1NJ20374F.

(51) Perisé-Barrios, A. J.; Fuentes-Paniagua, E.; Sánchez-Nieves, J.; Serramía, M. J.; Alonso, E.; Reguera, R. M.; Gómez, R.; de la Mata, F. J.; Muñoz-Fernández, M. Á. Mol. Pharmaceutics 2016, 13, 3427. doi:10.1021/acs.molpharmaceut.6b00420.

(52) Fuentes-Paniagua, E.; Peña-González, C. E.; Galán, M.; Gómez, R.; de la Mata, F. J.; Sánchez-Nieves, J. Organometallics 2013, 32, 1789. doi:10.1021/ om301217g.

(53) Downing, C. M.; Missaghi, M. N.; Kung, M. C.; Kung, H. H. Tetrahedron 2011, 67, 7502. doi:10.1016/j.tet.2011.07.068.

(54) Wolf, C.; Pirkle, W. H. J. Chromatogr. A 1998, 799, 177. doi:10.1016/S00219673(97)01063-7.

(55) Clinical laboratory testing and in vitro diagnostic test systems - Susceptibility testing of infectious agents and evaluation of performance of antimicrobial susceptibility test devices - Part 1: Reference methods for the testing the in vitro activity of antimicrobial agents against bacteria involved in infectious diseases; ISO 20776-1, 2016.

(56) Montañez, M. I.; Mayorga, C.; Torres, M. J.; Blanca, M.; Perez-Inestrosa, E. Nanomedicine-Nanotechnol., Biol., Med. 2011, 7, 682. doi:10.1016/j.nano.2011.07. 008.

(57) Llinás, A.; Vilanova, B.; Muñoz, F.; Donoso, J. J. Mol. Catal. A: Chem. 2001, 175 , 3. doi:10.1016/S1381-1169(01)00203-5. 


\section{Pagination not final (cite DOI) / Pagination provisoire (citer le DOI)}

(58) Sánchez-Nieves, J.; Ortega, P.; Muñoz-Fernández, M. Á.; Gómez, R.; de la Mata, F. J. Tetrahedron 2010, 66, 9203. doi:10.1016/j.tet.2010.09.063.

(59) Pedziwiatr-Werbicka, E.; Fuentes, E.; Dzmitruk, V.; Sánchez-Nieves, J.; Sudas, M.; Drozd, E.; Shakhbazau, A.; Shcharbin, D.; de la Mata, F. J.; Gómez-Ramírez, R.; Muñoz-Fernández, M. Á.; Bryszewska, M. Colloids Surf., B 2013, 109, 183. doi:10.1016/j.colsurfb.2013.03.045.
(60) Zhang, J.; Chen, Y.-P.; Miller, K. P.; Ganewatta, M. S.; Bam, M.; Yan, Y.; Nagarkatti, M.; Decho, A. W.; Tang, C. J. Am. Chem. Soc. 2014, 136, 4873. doi:10.1021/ja5011338.

(61) Mucsi, Z.; Chass, G. A.; Ábrányi-Balogh, P.; Jójárt, B.; Fang, D.-C.; Ramírez-Cuesta, A. J.; Viskolcz, B.; Csizmadia, I. G. Phys. Chem. Chem. Phys. 2013, 15, 20447. doi:10.1039/c3cp50868d. 
For Supporting Information

\section{Strategies for Penicillin V dendronization with cationic carbosilane dendrons and study of antibacterial properties}

Elena Fuentes-Paniagua, ${ }^{[\mathrm{a}],[\mathrm{b}]}$ José M. Hernández-Ros, ${ }^{[\mathrm{c}]}$ Juan Soliveri, ${ }^{[\mathrm{c}]}$ José L. Copa-Patiño, ${ }^{[\mathrm{c}]}$ Rafael Gómez, ${ }^{[\mathrm{a}],[\mathrm{b}]}$ Javier Sánchez-Nieves, ${ }^{[\mathrm{a}],[\mathrm{b}],{ }^{*}}$ F. Javier de la Mata, ${ }^{[\mathrm{a}],[\mathrm{b}], *}$

[a] Departamento de Química Orgánica y Química Inorgánica, Campus Universitario, Universidad de Alcalá, Alcalá de Henares (Spain); javier.delamata@uah.es;

[b] Networking Research Center on Bioengineering, Biomaterials and Nanomedicine (CIBER-BBN), Spain; FAX: (+34) 91885 4683; e-mail: rafael.gomez@uah.es;

[c] Departamento de Biomedicina y Biotecnología, Campus Universitario, Universidad de Alcalá, Alcalá de Henares, Spain; e-mail: josel.copa@uah.es 


\section{S.1. Experimental Section}

S.1.1. General Considerations. All reactions were carried out under inert atmosphere and solvents were purified from appropriate drying agents when necessary. NMR spectra were recorded on a Varian Unity VXR-300 (300.13 $\left.\left({ }^{1} \mathrm{H}\right), 75.47\left({ }^{13} \mathrm{C}\right) \mathrm{MHz}\right)$ or on a Bruker AV400 (400.13 $(1 \mathrm{H}), 100.60\left({ }^{13} \mathrm{C}\right), 40.56$ $\left.\left({ }^{15} \mathrm{~N}\right), 79.49\left({ }^{29} \mathrm{Si}\right) \mathrm{MHz}\right)$. Chemical shifts $(\delta)$ are given in ppm. ${ }^{1} \mathrm{H}$ and ${ }^{13} \mathrm{C}$ resonances were measured relative to internal deuterated solvent peaks considering TMS $=0 \mathrm{ppm}$, meanwhile ${ }^{29} \mathrm{Si}$ resonances were measured relative to external TMS employing ${ }^{1} \mathrm{H}_{-}{ }^{29} \mathrm{Si} \mathrm{HMBC}$ experiments. When necessary, assignment of resonances was done from HSQC, HMBC, COSY, TOCSY and NOESY NMR experiments. Thiol-ene reactions were carried out employing a HPK $125 \mathrm{~W}$ mercury lamp from Heraeus Noblelight with maximum energy at $365 \mathrm{~nm}$, in normal glassware under an inert atmosphere. Elemental analyses were performed on a LECO CHNS-932. Mass Spectra were obtained from an Agilent 6210. Compounds, $\mathrm{HS}\left(\mathrm{CH}_{2}\right)_{2} \mathrm{NMe}_{2} \cdot \mathrm{HCl}$ (Acros), 2,2'-dimethoxy-2-phenylacetophenone (DMPA) (Aldrich), MeI (Aldrich), HSiMe $2 \mathrm{Cl}$ (ABCR), $\mathrm{HSiMeCl}_{2}$ (Aldrich), $\mathrm{LiAlH}_{4}$ (Acros), $\mathrm{K}_{2} \mathrm{CO}_{3}$ (Panreac), penicillin $\mathrm{V}$ potassium salt (PenVK), platinum(0)-1,3-divinyl-1,1,3,3-tetramethyldisiloxane complex solution (Karsted's catalyst), porcine liver esterease (PLE) were obtained from commercial sources. Compounds $\mathrm{NH}_{2} \mathrm{G}_{\mathrm{n}}\left(\mathrm{NMe}_{2}\right)_{\mathrm{m}}{ }^{1}$ $\left[\mathrm{NH}_{2} \mathrm{G}_{\mathrm{n}}\left(\mathrm{S}-\mathrm{NMe}_{3}\right)_{\mathrm{m}}\right]^{\mathrm{m}+1},{ }^{2} \mathrm{ClG}_{1} \mathrm{~V}_{2},{ }^{3}$ and $\mathrm{ClG}_{1} \mathrm{~A}_{2}{ }^{4}$ were synthesized as published.

\section{S.1.2. Synthesis of compounds.}

PenG $_{1} V_{2}$ (1). PenVK (0.177 g, $\left.0.46 \mathrm{mmol}\right)$ and $\mathrm{BrG}_{1} \mathrm{~V}_{2}(0.119 \mathrm{~g}, 0.46 \mathrm{mmol})$ were heated $\left(80{ }^{\circ} \mathrm{C}\right)$ in a sealed ampoule in DMF in presence of $18 \mathrm{C} 6(0.012 \mathrm{~g}, 0.04 \mathrm{mmol})$ and catalytic amounts of NaI overnight. Then, volatiles were removed and $\mathrm{CH}_{2} \mathrm{Cl}_{2} / \mathrm{H}_{2} \mathrm{O}(\mathrm{NaCl})$ extraction was performed and the organic phase was dried over $\mathrm{MgSO}_{4}$ and $\mathrm{SiO}_{2}$. Finally, dendron $1(0.157 \mathrm{~g}, 64 \%)$ was obtained after removing the volatiles.

${ }^{1} \mathrm{H}-\mathrm{NMR}\left(\mathrm{CDCl}_{3}\right): \delta-0.02(\mathrm{~s}, 3 \mathrm{H}, \mathrm{SiMe}), 0.56\left(\mathrm{t}, \mathrm{J}_{\mathrm{a}}=8.5 \mathrm{~Hz}, 2 \mathrm{H}, \mathrm{SiCH}_{2}\right), 1.38\left(\mathrm{~m}, 4 \mathrm{H}, \mathrm{CH}_{2} \mathrm{CH}_{2} \mathrm{Si}\right)$, $1.48\left(\mathrm{~s}, 3 \mathrm{H}, \mathrm{CMe} e_{2}\right), 1.58\left(\mathrm{~s}, 3 \mathrm{H}, \mathrm{CMe}_{2}\right), 1.68\left(\mathrm{~m}, 2 \mathrm{H}, \mathrm{OCH}_{2} \mathrm{CH}_{2}\right), 4.16\left(\mathrm{~m}, 2 \mathrm{H},(\mathrm{CO}) \mathrm{OCH}_{2}\right), 4.44(\mathrm{~s}, 1 \mathrm{H}$, $\mathrm{CH}(\mathrm{CO})), 4.54\left(\mathrm{~s}, 2 \mathrm{H}, \mathrm{OCH}_{2} \mathrm{CO}\right), 5.56\left(\mathrm{~d}, \mathrm{~J}_{\mathrm{b}}=4.1 \mathrm{~Hz}, 1 \mathrm{H}, \mathrm{CHS}\right), 5.70\left(\mathrm{~m}, 3 \mathrm{H}, \mathrm{NHCH}, \mathrm{SiCHCH}_{2}\right), 6.03$ 
$\left(\mathrm{m}, 4 \mathrm{H}, \mathrm{SiCHCH} H_{2}\right), 6.91\left(\mathrm{~d}, \mathrm{~J}_{\mathrm{c}}=7.9 \mathrm{~Hz}, 2 \mathrm{H}, \mathrm{CH} H_{\mathrm{Ar}}\right), 7.01\left(\mathrm{t}, \mathrm{J}_{\mathrm{d}}=7.4 \mathrm{~Hz}, 1 \mathrm{H}, \mathrm{CH}_{\mathrm{Ar}}\right), 7.31\left(\mathrm{~m}, 2 \mathrm{H}, \mathrm{CH}_{\mathrm{Ar}}\right)$. ${ }^{13} \mathrm{C}\left\{{ }^{1} \mathrm{H}\right\}-\mathrm{NMR}\left(\mathrm{CDCl}_{3}\right): \delta$-5.9 (SiMe), $12.6\left(\mathrm{CH}_{2} \mathrm{Si}\right), 20.1\left(\mathrm{CH}_{2} \mathrm{CH}_{2} \mathrm{Si}\right), 26.8$ and $32.1(\mathrm{SCMe} 2), 31.9$ $\left(\mathrm{CH}_{2} \mathrm{CH}_{2} \mathrm{CH}_{2} \mathrm{Si}\right), 58.0(\mathrm{NHCH}), 64.7\left(\mathrm{SCMe}_{2}\right), 65.4\left(\mathrm{COOCH}_{2}\right), 67.1\left(\mathrm{OCH}_{2} \mathrm{CO}\right), 67.8(C H S), 70.5$ (CHCOO), $114.7\left(\mathrm{CH}_{\mathrm{Ar}}\right), 122.4\left(\mathrm{CH}_{\mathrm{Ar}}\right), 129.8\left(\mathrm{CH}_{\mathrm{Ar}}\right), 133.1\left(\mathrm{SiCHCH}_{2}\right), 136.6(\mathrm{SiCHCH}), 156.9\left(C \mathrm{C}_{\mathrm{Ar}}\right)$, 167.6, 167.8 and $173.0(C=\mathrm{O})$. MALDI: $[\mathrm{M}+\mathrm{Na}]^{+}=525.19$ uma (calcd. $=525.19$ uma). Anal. Calcd. $\mathrm{C}_{25} \mathrm{H}_{34} \mathrm{~N}_{2} \mathrm{O}_{5} \mathrm{SSi}(502.70$ g/mol): C, 59.73; H, 6.82; N, 5.57;Exp.: C, 60.22; H, 7.48; N, 6.16.

$\mathrm{ClG}_{1}\left(\mathrm{~S}_{\mathbf{N}} \mathrm{NMe}_{2} \cdot \mathbf{H C l}\right)_{2}$ (2). A mixture of $\mathrm{ClG}_{1} \mathrm{~V}_{2}(0.200 \mathrm{~g}, 1.14 \mathrm{mmol})$, 2-(dimethylamino)ethanethiol hydrochloride $(0.331 \mathrm{~g}, 2.34 \mathrm{mmol})$ and DMPA $(0.054 \mathrm{~g}, 0.21 \mathrm{mmol})$ in THF/MeOH $(2 \mathrm{~mL} / 8 \mathrm{~mL})$ were stirred under inert atmosphere and UV irradiated for $5 \mathrm{~h}$. The amount of DMPA was added in two portions, one at the beginning of reaction and one after $2 \mathrm{~h}$. Next, volatiles were removed under vacuum and the remaining solid was solved in the minimum amount of $\mathrm{MeOH}$ and precipitated with $\mathrm{Et}_{2} \mathrm{O}$ (twice) to afford 2 as pale yellow solid $(0.383 \mathrm{~g}, 76 \%)$.

${ }^{1} \mathrm{H}-\mathrm{NMR}\left(\mathrm{DMSO}_{-} \mathrm{d}_{6}\right): \delta-0.06(\mathrm{~s}, 3 \mathrm{H}, \mathrm{SiMe}), 0.59\left(\mathrm{~m}, 2 \mathrm{H}, \mathrm{SiCH}_{2}\right), 0.87\left(\mathrm{t}, \mathrm{J}_{\mathrm{a}}=8.3 \mathrm{~Hz}, 4 \mathrm{H}\right.$, $\left.\mathrm{SiCH}_{2} \mathrm{CH}_{2} \mathrm{~S}\right), 1.66\left(\mathrm{~m}, 2 \mathrm{H}, \mathrm{ClCH}_{2} \mathrm{CH}_{2}\right), 2.60\left(\mathrm{t}, \mathrm{J}_{\mathrm{a}}=8.3 \mathrm{~Hz}, 4 \mathrm{H}, \mathrm{SiCH}_{2} \mathrm{CH}_{2} \mathrm{~S}\right), 2.73(\mathrm{~s}, 12 \mathrm{H},-\mathrm{NMe} \cdot \mathrm{HCl})$, $2.85\left(\mathrm{t}, \mathrm{J}_{\mathrm{b}}=7.4 \mathrm{~Hz}, 4 \mathrm{H}, \mathrm{SCH}_{2} \mathrm{CH}_{2} \mathrm{~N}^{+}\right), 3.20\left(\mathrm{t}, \mathrm{J}_{\mathrm{b}}=7.4 \mathrm{~Hz}, 4 \mathrm{H}, \mathrm{SCH}_{2} \mathrm{CH}_{2} \mathrm{~N}^{+}\right), 3.59\left(\mathrm{t}, \mathrm{J}_{\mathrm{c}}=6.5 \mathrm{~Hz}, 2 \mathrm{H}\right.$, $\left.\mathrm{ClCH}_{2}\right) .{ }^{13} \mathrm{C}\left\{{ }^{1} \mathrm{H}\right\}-\mathrm{NMR}\left(\mathrm{DMSO}_{6}\right): \delta-5.71(\mathrm{SiMe}), 10.4\left(\mathrm{ClCH}_{2} \mathrm{CH}_{2} \mathrm{CH}_{2}\right), 13.5\left(\mathrm{SiCH}_{2} \mathrm{CH}_{2} \mathrm{~S}\right), 24.2$ $\left(\mathrm{SCH}_{2} \mathrm{CH}_{2} \mathrm{~N}^{+}\right), 26.0\left(\mathrm{SiCH}_{2} \mathrm{CH}_{2} \mathrm{~S}\right), 26.8\left(\mathrm{ClCH}_{2} \mathrm{CH}_{2}\right), 41.4(-\mathrm{NMe} \cdot \mathrm{HCl}), 47.9\left(\mathrm{ClCH}_{2}\right), 55.3\left(\mathrm{CH}_{2} \mathrm{~N}^{+}\right) .{ }^{15} \mathrm{~N}-$ NMR (DMSO-d $\left.{ }_{6}\right):-339.0\left(-\mathrm{NMe}_{2} \mathrm{H}^{+}\right) .{ }^{29} \mathrm{Si}-\mathrm{NMR}\left(\mathrm{DMSO}-\mathrm{d}_{6}\right): \delta 2.2 . \mathrm{ESI}: \mathrm{q}=1\left(421.17[\mathrm{M}-\mathrm{Cl}]^{+}\right)$. Anal. Calc. $\mathrm{C}_{16} \mathrm{H}_{39} \mathrm{Cl}_{3} \mathrm{~N}_{2} \mathrm{~S}_{2} \mathrm{Si}(458.07 \mathrm{~g} / \mathrm{mol}): \mathrm{C}, 41.95 ; \mathrm{H}, 8.58 ; \mathrm{N}, 6.12 ; \mathrm{S}, 14.00 ;$ Exp.: C, 41.94; H, 8.93; N, 5.49; S, 11.44 .

$\mathbf{C l G}_{1}\left(\mathbf{S}_{-} \mathrm{NMe}_{2}\right)_{2}$ (3). This dendrimer was obtained mixing $2(0.210 \mathrm{~g}, 0.41 \mathrm{mmol})$ and $\mathrm{Na}_{2} \mathrm{CO}_{3}(0.092 \mathrm{~g}$, $0.87 \mathrm{mmol}$ ) in $\mathrm{CHCl}_{3} / \mathrm{H}_{2} \mathrm{O}$, extracting the organic fraction and removing the solvent under vacuum. This procedure yielded 3 as a yellowish oil $(0.174 \mathrm{~g}, 98 \%)$.

${ }^{1} \mathrm{H}-\mathrm{NMR}\left(\mathrm{CDCl}_{3}\right): \delta-0.06(\mathrm{~s}, 3 \mathrm{H}, \mathrm{SiMe}), 0.58\left(\mathrm{~m}, 2 \mathrm{H}, \mathrm{ClCH}_{2} \mathrm{CH}_{2} \mathrm{CH}_{2} \mathrm{Si}\right), 0.88\left(\mathrm{t}, \mathrm{J}_{\mathrm{a}}=8.7 \mathrm{~Hz}, 4 \mathrm{H}\right.$, $\left.\mathrm{SiCH}_{2} \mathrm{CH}_{2} \mathrm{~S}\right), 1.70\left(\mathrm{~m}, 2 \mathrm{H}, \mathrm{ClCH}_{2} \mathrm{CH}_{2}\right), 2.24\left(\mathrm{~s}, 12 \mathrm{H},-\mathrm{NMe}\right.$ ), $2.47\left(\mathrm{~m}, 4 \mathrm{H}, \mathrm{SCH}_{2} \mathrm{CH}_{2} \mathrm{~N}\right), 2.52(\mathrm{~m}, 4 \mathrm{H}$, 
$\left.\mathrm{SiCH}_{2} \mathrm{CH}_{2} \mathrm{~S}\right), 2.59\left(\mathrm{~m}, 4 \mathrm{H}, \mathrm{SCH}_{2} \mathrm{CH}_{2} \mathrm{~N}\right), 3.49\left(\mathrm{t}, \mathrm{J}_{\mathrm{b}}=6.8 \mathrm{~Hz}, 2 \mathrm{H}, \mathrm{ClCH}_{2}\right) .{ }^{13} \mathrm{C}\left\{{ }^{1} \mathrm{H}\right\}-\mathrm{NMR}\left(\mathrm{CDCl}_{3}\right): \delta-5.3$ (MeSi), $11.5\left(\mathrm{ClCH}_{2} \mathrm{CH}_{2} \mathrm{CH}_{2}\right), 14.6\left(\mathrm{SiCH}_{2} \mathrm{CH}_{2} \mathrm{~S}\right), 27.7\left(\mathrm{SiCH}_{2} \mathrm{CH}_{2} \mathrm{~S}\right), 29.9\left(\mathrm{SCH}_{2} \mathrm{CH}_{2} \mathrm{NMe}_{2}\right), 45.4(-$ $\mathrm{NMe} 2), 48.1\left(\mathrm{ClCH}_{2}\right), 59.3\left(\mathrm{SCH}_{2} \mathrm{CH}_{2} \mathrm{NMe}_{2}\right) .{ }^{29} \mathrm{Si}-\mathrm{NMR}\left(\mathrm{CDCl}_{3}\right): \delta 2.1 . \mathrm{MALDI}:[\mathrm{M}+\mathrm{H}]^{+}=385.19$ uma. Anal. Calc. $\mathrm{C}_{16} \mathrm{H}_{37} \mathrm{ClN}_{2} \mathrm{~S}_{2} \mathrm{Si}(385.15$ g/mol): C, 49.90; H, 9.68; N, 7.27; S, 16.65; Exp.: C, 48.99; H, 10.38; $\mathrm{N}, 6.81 ; \mathrm{S}, 16.84$.

$\mathbf{C l G}_{1}\left(\mathbf{S}_{-}-\mathrm{NMe}_{3} \mathrm{I}\right)_{2}$ (4). A mixture of $3(0.175 \mathrm{~g}, 0.45 \mathrm{mmol})$ and MeI $(0.06 \mathrm{~mL}, 0.96 \mathrm{mmol})$ was stirred in THF for $16 \mathrm{~h}$. Afterward, volatiles were removed under vacuum and the remainnig solid was washed with $\mathrm{Et}_{2} \mathrm{O}(2 \times 50 \mathrm{~mL})$ to obtain 4 as a white solid $(0.268 \mathrm{~g}, 89 \%)$.

${ }^{1} \mathrm{H}-\mathrm{NMR}\left(\mathrm{DMSO}_{6}\right): \delta-0.06(\mathrm{~s}, 3 \mathrm{H}, \mathrm{SiMe}), 0.56\left(\mathrm{~m}, 2 \mathrm{H}, \mathrm{ClCH}_{2} \mathrm{CH}_{2} \mathrm{CH}_{2} \mathrm{Si}\right), 0.85(\mathrm{~m}, 4 \mathrm{H}$, $\mathrm{SiCH}_{2} \mathrm{CH}_{2} \mathrm{~S}$ ), $1.67\left(\mathrm{~m}, 2 \mathrm{H}, \mathrm{ClCH}_{2} \mathrm{CH}_{2} \mathrm{CH}_{2} \mathrm{Si}\right.$ ), 2.56 (m, $\left.4 \mathrm{H}, \mathrm{SiCH}_{2} \mathrm{CH}_{2} \mathrm{~S}\right), 2.88\left(\mathrm{~m}, 4 \mathrm{H}, \mathrm{SCH}_{2} \mathrm{CH}_{2} \mathrm{~N}^{+}\right.$), $3.07\left(\mathrm{~s}, 18 \mathrm{H},-\mathrm{NMe}_{3}{ }^{+}\right), 3.49\left(\mathrm{~m}, 4 \mathrm{H}, \mathrm{SCH}_{2} \mathrm{CH}_{2} \mathrm{~N}^{+}\right), 3.57\left(\mathrm{~m}, 2 \mathrm{H}, \mathrm{ClCH}{ }_{2}\right) .{ }^{13} \mathrm{C}\left\{{ }^{1} \mathrm{H}\right\}-\mathrm{NMR}\left(\mathrm{DMSO}-\mathrm{d}_{6}\right): \delta-$ 5.7 (MeSi), $10.3\left(\mathrm{ClCH}_{2} \mathrm{CH}_{2} \mathrm{CH}_{2} \mathrm{Si}\right), 13.5\left(\mathrm{SiCH}_{2} \mathrm{CH}_{2} \mathrm{~S}\right), 23.1\left(\mathrm{SCH}_{2} \mathrm{CH}_{2} \mathrm{~N}^{+}\right), 26.3\left(\mathrm{SiCH}_{2} \mathrm{CH}_{2} \mathrm{~S}\right), 26.8$ $\left(\mathrm{ClCH}_{2} \mathrm{CH}_{2}\right), 47.9\left(\mathrm{ClCH}_{2}\right), 51.6\left(-\mathrm{NMe}_{3}{ }^{+}\right), 63.9\left(\mathrm{CH}_{2} \mathrm{~N}^{+}\right) .{ }^{15} \mathrm{~N}-\mathrm{NMR}\left(\mathrm{DMSO}-\mathrm{d}_{6}\right): \delta-330.1\left(-\mathrm{NMe}_{3}{ }^{+}\right) .{ }^{29} \mathrm{Si}^{-}$ NMR (DMSO-d $\left.{ }_{6}\right): \delta$ 2.5. ESI: $\mathrm{q}=2\left(213.12[\mathrm{M}-2 \mathrm{I}]^{2+}\right)$. Anal. Calc. $\mathrm{C}_{18} \mathrm{H}_{43} \mathrm{ClI}_{2} \mathrm{~N}_{2} \mathrm{~S}_{2} \mathrm{Si}(669.02 \mathrm{~g} / \mathrm{mol}): \mathrm{C}$, 32.31; H, 6.48; N, 4.19; S, 9.59; Obt.: C, 31.69; H, 5.93; N, 3.96; S, 8.96.

$\mathbf{C l G}_{1}(\mathrm{SiCl})_{2}$ (5). A teflon-valve ampoule containing a solution of $\mathrm{ClG}_{1} \mathrm{~A}_{2}(1.000 \mathrm{~g}, 4.93 \mathrm{mmol})$ and Kardsted's catalyst $(3 \% \mathrm{~mol})$ in hexane $(2 \mathrm{~mL})$ was cooled to $0^{\circ} \mathrm{C}$ and $\mathrm{HSiMe}_{2} \mathrm{Cl}(2.15 \mathrm{~mL}, 19.77 \mathrm{mmol})$ was slowly added. After $30 \mathrm{~min}$ stirring at this temperature, the solution was warmed until $60^{\circ} \mathrm{C}$ and stirred for $4 \mathrm{~h}$. Afterwards, volatiles were removed under vacuum, hexane was added $(20 \mathrm{~mL})$ and the solution was filtered through active carbon. Removal of volatiles under vacuum gave $\mathbf{5}$ as colorless oil $(1.914 \mathrm{~g}, 99 \%)$. This product is moisture sensitive and has to be stored under inert atmosphere.

${ }^{1} \mathrm{H}-\mathrm{NMR}\left(\mathrm{CDCl}_{3}\right): \delta-0.05$ (s, $\left.3 \mathrm{H}, \mathrm{MeSi}\right), 0.38\left(\mathrm{~s}, 12 \mathrm{H}, \mathrm{Me}_{2} \mathrm{SiCl}\right), 0.52\left(\mathrm{~m}, 6 \mathrm{H}, \mathrm{SiCH}_{2}\right), 0.88(\mathrm{~m}, 4 \mathrm{H}$, $\left.\mathrm{CH}_{2} \mathrm{SiCl}\right), 1.25\left(\mathrm{~m}, 6 \mathrm{H}, \mathrm{CH}_{2}\right), 1.85\left(\mathrm{~m}, 2 \mathrm{H}, \mathrm{ClCH}_{2} \mathrm{CH}_{2}\right), 3.47\left(\mathrm{t}, \mathrm{J}=6.9 \mathrm{~Hz}, 2 \mathrm{H}, \mathrm{ClCH}_{2}\right) .{ }^{13} \mathrm{C}\left\{{ }^{1} \mathrm{H}\right\}-\mathrm{NMR}$ $\left(\mathrm{CDCl}_{3}\right)$ : -5.2 (MeSi), $1.8\left(\mathrm{Me}_{2} \mathrm{Si}\right), 11.4\left(\mathrm{ClCH}_{2} \mathrm{CH}_{2} \mathrm{CH}_{2}\right), 17.6\left(\mathrm{CH}_{2}\right), 17.8\left(\mathrm{CH}_{2}\right), 23.4\left(\mathrm{CH}_{2} \mathrm{SiCl}\right), 27.6$ $\left(\mathrm{ClCH}_{2} \mathrm{CH}_{2}\right), 48.0\left(\mathrm{ClCH}_{2}\right) .{ }^{29} \mathrm{Si}-\mathrm{NMR}\left(\mathrm{CDCl}_{3}\right): 2.3(\mathrm{MeSi}), 31.1\left(\mathrm{Me}_{2} \mathrm{SiCl}\right)$. 
$\mathrm{ClG}_{1}(\mathrm{SiH})_{2}$ (6). An $\mathrm{Et}_{2} \mathrm{O}$ solution $(40 \mathrm{~mL})$ of $5(0.229 \mathrm{~g}, 0.58 \mathrm{mmol})$ was slowly added to an $\mathrm{Et}_{2} \mathrm{O}$ solution $(20 \mathrm{~mL})$ of $\mathrm{LiAlH}_{4}(0.33 \mathrm{~mL}, 0.66 \mathrm{mmol})$ at $0{ }^{\circ} \mathrm{C}$ and stirred overnight at room temperature. Afterward, the mixture was added over a saturated water solution of $\mathrm{NH}_{4} \mathrm{Cl}(50 \mathrm{~mL})$ at $0{ }^{\circ} \mathrm{C}$, the organic phase was separated and the aqueous phase was extracted twice with $\mathrm{Et}_{2} \mathrm{O}$. After drying the organic phase over $\mathrm{MgSO}_{4}$ and $\mathrm{SiO}_{2}$, the solution was filtered and the volatiles were removed under vacuum, yielding 6 as colorless oil $(0.145 \mathrm{~g}, 76 \%)$.

${ }^{1} \mathrm{H}-\mathrm{NMR}\left(\mathrm{CDCl}_{3}\right): \delta-0.06(\mathrm{~s}, 3 \mathrm{H}, \mathrm{MeSi}), 0.04\left(\mathrm{~d}, \mathrm{~J}=3.8 \mathrm{~Hz}, 12 \mathrm{H}, \mathrm{Me}_{2} \mathrm{SiH}\right), 0.60\left(\mathrm{~m}, 10 \mathrm{H}, \mathrm{SiCH}_{2}\right)$, $1.36\left(\mathrm{~m}, 4 \mathrm{H}, \mathrm{SiCH}_{2} \mathrm{CH}_{2} \mathrm{CH}_{2} \mathrm{Si}\right), 1.72\left(\mathrm{~m}, 2 \mathrm{H}, \mathrm{ClCH}_{2} \mathrm{CH}_{2}\right), 3.48\left(\mathrm{t}, \mathrm{J}=6.9 \mathrm{~Hz}, 2 \mathrm{H}, \mathrm{ClCH}_{2}\right), 3.82(\mathrm{~m}, 2 \mathrm{H}$, $\mathrm{SiH}) ;{ }^{13} \mathrm{C}\left\{{ }^{1} \mathrm{H}\right\}-\mathrm{NMR}\left(\mathrm{CDCl}_{3}\right): \delta$-5.2 $(\mathrm{MeSi}),-4.4\left(\mathrm{Me}_{2} \mathrm{SiH}\right), 11.6\left(\mathrm{ClCH}_{2} \mathrm{CH}_{2} \mathrm{CH}_{2}\right), 17.8,18.8$ and 18.9 $\left(\mathrm{SiCH}_{2} \mathrm{CH}_{2} \mathrm{CH}_{2} \mathrm{Si}\right), 27.7\left(\mathrm{ClCH}_{2} \mathrm{CH}_{2}\right), 48.1\left(\mathrm{ClCH}_{2}\right) .{ }^{29}{ }^{2} \mathrm{Si}-\mathrm{NMR}\left(\mathrm{CDCl}_{3}\right): \delta$-14.1 $\left(\mathrm{Me}_{2} \mathrm{SiH}\right), 2.3(\mathrm{MeSi})$. Anal. Calc. $\mathrm{C}_{14} \mathrm{H}_{35} \mathrm{ClSi}_{3}(323.14$ g/mol): C, 52.04; H, 10.92; Obt.: C, 52.45; H, 10.60 .

$\mathbf{C l G}_{2}\left(\mathbf{S i M e C l}_{2}\right)_{2}$ (7). $\mathrm{HSiMeCl}_{2}(5.1 \mathrm{~mL}, 49.46 \mathrm{mmol})$ was added to a cooled $\left(0^{\circ} \mathrm{C}\right)$ teflon-valve ampoule containing a solution of $\mathrm{ClG}_{1} \mathrm{~A}_{2}(2.506 \mathrm{~g}, 12.37 \mathrm{mmol})$ and Kardsted's catalyst $(3 \% \mathrm{~mol})$ in hexane $(3 \mathrm{~mL})$ and the solution was stirred for $4 \mathrm{~h}$ at $60^{\circ} \mathrm{C}$. Afterward, volatiles were removed under vacuum, hexane was added $(10 \mathrm{~mL})$ and the solution was filtered through active carbon. Removal of volatiles under vacuum gave 7 as colorless liquid $(5.299 \mathrm{~g}, 99 \%)$. This product is moisture sensitive and has to be stored under inert atmosphere.

${ }^{1} \mathrm{H}-\mathrm{NMR}\left(\mathrm{CDCl}_{3}\right): \delta-0.01$ (s, $\left.6 \mathrm{H}, \mathrm{Si} M e\right), 0.05$ (s, 3H, SiMe), $0.66\left(\mathrm{~m}, 6 \mathrm{H}, \mathrm{ClCH}_{2} \mathrm{CH}_{2} \mathrm{CH}_{2} \mathrm{SiCH}_{2}\right), 0.76$ (s, $6 \mathrm{H}, \mathrm{MeSiCl}_{2}$ ), 1.19 (m, $\left.4 \mathrm{H}, \mathrm{CH}_{2} \mathrm{SiMeCl}_{2}\right), 1.52$ (m, $\left.4 \mathrm{H}, \mathrm{SiCH}_{2} \mathrm{CH}_{2} \mathrm{CH}_{2} \mathrm{Si}\right), 1.74\left(\mathrm{~m}, 2 \mathrm{H}, \mathrm{ClCH}_{2} \mathrm{CH}_{2}\right.$ ), $3.50\left(\mathrm{t}, \mathrm{J}=7.0 \mathrm{~Hz}, 2 \mathrm{H}, \mathrm{ClCH}_{2}\right) ;{ }^{13} \mathrm{C}\left\{{ }^{1} \mathrm{H}\right\}-\mathrm{NMR}\left(\mathrm{CDCl}_{3}\right): \delta$-5.3 $(\mathrm{SiMe}), \quad 5.4\left(\mathrm{MeSiCl}_{2}\right), 11.2$ $\left(\mathrm{ClCH}_{2} \mathrm{CH}_{2} \mathrm{CH}_{2}\right), 17.2\left(\mathrm{SiCH}_{2}\right), 17.2\left(\mathrm{SiCH}_{2} \mathrm{CH}_{2}\right), 25.8\left(\mathrm{CH}_{2} \mathrm{SiCl}_{2}\right), 27.5\left(\mathrm{ClCH}_{2} \mathrm{CH}_{2}\right), 47.9\left(\mathrm{ClCH}_{2}\right)$; ${ }^{29} \mathrm{Si}-$ $\operatorname{NMR}\left(\mathrm{CDCl}_{3}\right): \delta 2.3(\mathrm{MeSi}), 32.2\left(\mathrm{MeSiCl}_{2}\right)$.

$\mathbf{C l G}_{2} \mathbf{A}_{4}$ (8). $\operatorname{BrMg}\left(\mathrm{C}_{3} \mathrm{H}_{5}\right)(59.4 \mathrm{~mL}, 59.40 \mathrm{mmol})$ was slowly added to a cooled $\mathrm{Et}_{2} \mathrm{O}$ solution of $\mathrm{ClG}_{2}\left(\mathrm{SiMeCl}_{2}\right)_{2}(5.299 \mathrm{~g}, 12.40 \mathrm{mmol})$. The reaction mixture was refluxed for 3 hours and afterwards stirred overnight at room temperature. $\mathrm{Next}$, a water solution of $\mathrm{NH}_{4} \mathrm{Cl}$ was added $(12 \%)$, the organic phase 
was separated and the aqueous phase was extracted twice with $\mathrm{Et}_{2} \mathrm{O}$. The organic phase was washed with brine, dried over $\mathrm{MgSO}_{4}$ and $\mathrm{SiO}_{2}$. The solution was filtered through active carbon and the volatiles were removed under vacuum, yielding 8 as colorless liquid (5.246 g, $94 \%$ ).

${ }^{1} \mathrm{H}-\mathrm{NMR}\left(\mathrm{CDCl}_{3}\right): \delta-0.07$ (s, $\left.3 \mathrm{H}, \mathrm{MeSi}\right),-0.03\left(\mathrm{~s}, 6 \mathrm{H}, \mathrm{MeSi}\left(\mathrm{C}_{3} \mathrm{H}_{5}\right)_{2}\right), 0.58\left(\mathrm{~m}, 8 \mathrm{H}, \mathrm{CH}_{2} \mathrm{Si}\right), 1.32(\mathrm{~m}, 4$ $\left.\mathrm{H}, \mathrm{SiCH}_{2} \mathrm{CH}_{2} \mathrm{CH}_{2} \mathrm{Si}\right), 1.52\left(\mathrm{~d}, \mathrm{~J}_{\mathrm{b}}=8.2 \mathrm{~Hz}, 8 \mathrm{H}, \mathrm{SiCH}_{2} \mathrm{CH}\right), 1.72\left(\mathrm{~m}, 2 \mathrm{H}, \mathrm{ClCH}_{2} \mathrm{CH}_{2}\right), 3.47\left(\mathrm{t}, \mathrm{J}_{\mathrm{c}}=6.9 \mathrm{~Hz}\right.$, $\left.2 \mathrm{H}, \mathrm{ClCH}_{2}\right), 4.83\left(\mathrm{~m}, 8 \mathrm{H}, \mathrm{CH}=\mathrm{CH}_{2}\right), 5.75\left(\mathrm{~m}, 4 \mathrm{H}, \mathrm{CH}=\mathrm{CH}_{2}\right) .{ }^{13} \mathrm{C}\left\{{ }^{1} \mathrm{H}\right\}-\mathrm{NMR}\left(\mathrm{CDCl}_{3}\right): \delta \quad-5.8$ $\left(\mathrm{MeSi}\left(\mathrm{C}_{3} \mathrm{H}_{5}\right)_{2}\right),-5.2(\mathrm{MeSi}), \quad 11.5\left(\mathrm{ClCH}_{2} \mathrm{CH}_{2} \mathrm{CH}_{2}\right), \quad 17.9, \quad 18.1$ and $18.5\left(\mathrm{SiCH}_{2} \mathrm{CH}_{2} \mathrm{CH}_{2} \mathrm{Si}\right), 21.3$ $\left(\mathrm{CH}_{2} \mathrm{CH}=\mathrm{CH}_{2}\right), 27.7\left(\mathrm{ClCH}_{2} \mathrm{CH}_{2}\right), 48.0\left(\mathrm{ClCH}_{2}\right), 113.0\left(\mathrm{CH}=\mathrm{CH}_{2}\right), 134.8\left(\mathrm{CH}=\mathrm{CH}_{2}\right) ;{ }^{29} \mathrm{Si}-\mathrm{NMR}\left(\mathrm{CDCl}_{3}\right)$ : $2.0\left(\mathrm{G}_{1}-\mathrm{SiMe}\right), 0.1\left(\mathrm{G}_{2}-\mathrm{SiMe}\right)$. Anal. Calc. $\mathrm{C}_{25} \mathrm{H}_{49} \mathrm{ClSi}_{3}$ (469.37 g/mol): C, 63.97; H, 10.52; Exp.: C, 65.60; $\mathrm{H}, 10.10$.

$\mathrm{ClG}_{2}(\mathrm{SiCl})_{4}$ (9). This product was synthesized following the synthetic procedure described for 5 from 8 (1.058 g, $2.33 \mathrm{mmol})$ and $\mathrm{HSiMe}_{2} \mathrm{Cl}(2.0 \mathrm{~mL}, 18.38 \mathrm{mmol})$, obtainen 9 as colorless oil (1.861 g, $\left.96 \%\right)$.

${ }^{1} \mathrm{H}-\mathrm{NMR}\left(\mathrm{CDCl}_{3}\right): \delta-0.07$ (s, $\left.6 \mathrm{H}, \mathrm{MeSi}\right), 0.05$ (s, $\left.3 \mathrm{H}, \mathrm{Si} M e\right), 0.38$ (s, $\left.24 \mathrm{H}, M e_{2} \mathrm{SiCl}\right), 0.57$ (m, $18 \mathrm{H}$, $\left.\mathrm{SiCH}_{2}\right), 0.86\left(\mathrm{~m}, 8 \mathrm{H}, \mathrm{CH}_{2} \mathrm{SiCl}\right), 1.28\left(\mathrm{~m}, 4 \mathrm{H}, \mathrm{SiCH}_{2} \mathrm{CH}_{2} \mathrm{CH}_{2} \mathrm{Si}\right), 1.42\left(\mathrm{~m}, 8 \mathrm{H}, \mathrm{SiCH}_{2} \mathrm{CH}_{2} \mathrm{CH}_{2} \mathrm{Si}\right), 1.80$ $\left(\mathrm{m}, 2 \mathrm{H}, \mathrm{ClCH}_{2} \mathrm{CH}_{2}\right), 3.47\left(\mathrm{t}, \mathrm{J}=6.9 \mathrm{~Hz}, 2 \mathrm{H}, \mathrm{ClCH}_{2}\right) .{ }^{13} \mathrm{C}\left\{{ }^{1} \mathrm{H}\right\}-\mathrm{NMR}\left(\mathrm{CDCl}_{3}\right):-5.0(\mathrm{MeSi}), 1.8\left(\mathrm{Me}_{2} \mathrm{Si}\right)$, $11.6\left(\mathrm{ClCH}_{2} \mathrm{CH}_{2} \mathrm{CH}_{2}\right)$, 17.7-18.7 $\left(\mathrm{SiCH}_{2} \mathrm{CH}_{2} \mathrm{CH}_{2} \mathrm{Si}\right), 23.5\left(\mathrm{CH}_{2} \mathrm{SiCl}\right), 27.8\left(\mathrm{ClCH}_{2} \mathrm{CH}_{2}\right), 48.1\left(\mathrm{ClCH}_{2}\right)$; ${ }^{29} \mathrm{Si}-\mathrm{NMR}\left(\mathrm{CDCl}_{3}\right): 2.1(\mathrm{MeSi}), 31.1\left(\mathrm{Me}_{2} \mathrm{SiCl}\right)$.

$\mathrm{ClG}_{2}(\mathrm{SiH})_{4}(\mathbf{1 0})$. This product was obtained following the synthetic procedure described for 6 from 9 $(1.861 \mathrm{~g}, 2.24 \mathrm{mmol})$ and $\mathrm{LiAlH}_{4}(2.60 \mathrm{~mL}, 5.20 \mathrm{mmol})$, obtaining 10 as colorless oil $(1.158 \mathrm{~g}, 75 \%)$.

${ }^{1} \mathrm{H}-\mathrm{NMR}\left(\mathrm{CDCl}_{3}\right): \delta-0.09$ and $-0.06(\mathrm{~s}, 9 \mathrm{H}, \mathrm{MeSi}), 0.04\left(\mathrm{~d}, \mathrm{~J}=3.9 \mathrm{~Hz}, 24 \mathrm{H}, \mathrm{Me}_{2} \mathrm{SiH}\right), 0.59(\mathrm{~m}, 26 \mathrm{H}$, $\left.\mathrm{SiCH}_{2}\right), 1.36\left(\mathrm{~m}, 6 \mathrm{H}, \mathrm{SiCH}_{2} \mathrm{CH}_{2} \mathrm{CH}_{2} \mathrm{Si}\right), 1.72\left(\mathrm{~m}, 2 \mathrm{H}, \mathrm{ClCH}_{2} \mathrm{CH}_{2}\right), 3.48$ (t, J = 7.0 Hz, $\left.2 \mathrm{H}, \mathrm{ClCH}_{2}\right), 3.84$ $(\mathrm{m}, 4 \mathrm{H}, \mathrm{SiH}) .{ }^{13} \mathrm{C}\left\{{ }^{1} \mathrm{H}\right\}-\mathrm{NMR}\left(\mathrm{CDCl}_{3}\right): \delta$-5.0 (MeSi), -4.4 $\left(\mathrm{Me}_{2} \mathrm{SiH}\right), 11.7\left(\mathrm{ClCH}_{2} \mathrm{CH}_{2} \mathrm{CH}_{2}\right), 18.1-19.0$ $\left(\mathrm{SiCH}_{2} \mathrm{CH}_{2} \mathrm{CH}_{2} \mathrm{Si}\right), 27.8\left(\mathrm{ClCH}_{2} \mathrm{CH}_{2}\right), 48.1\left(\mathrm{ClCH}_{2}\right) .{ }^{29} \mathrm{Si}-\mathrm{NMR}\left(\mathrm{CDCl}_{3}\right): \delta$-14.1 $\left(\mathrm{Me}_{2} \mathrm{SiH}\right), 1.1\left(\mathrm{G}_{2}-\mathrm{SiMe}\right)$, $2.1\left(\mathrm{G}_{1}-\mathrm{SiMe}\right)$. Anal. Calc. $\mathrm{C}_{32} \mathrm{H}_{79} \mathrm{ClSi}_{7}$ (696.02 g/mol): C, 55.22; H, 11.44; Obt.: C, 56.45; H, 11.04 . 
$\mathbf{C l G}_{1}\left(\mathrm{Si}_{-} \mathrm{NMe}_{2}\right)_{2}$ (11). An excess of allyl-dimethylamine $(0.21 \mathrm{~mL}, 1.76 \mathrm{mmol})$ and two drops of Karsted's catalyst were added to a solution of $6(0.145 \mathrm{~g}, 0.44 \mathrm{mmol})$ in THF $(2 \mathrm{~mL})$. The reaction mixture was heated at $80{ }^{\circ} \mathrm{C}$ in a sealed ampoule under inert atmosphere for one night and then evaporated to dryness to remove the solvent and residual allyl-dimethylamine. Afterwards, hexane $(10 \mathrm{~mL})$ was added and the solution was filtered through active carbon and dried under vacuum to give $\mathbf{1 1}$ as pale yellow oil $(0.194 \mathrm{~g}, 88 \%)$.

${ }^{1} \mathrm{H}-\mathrm{NMR}\left(\mathrm{CDCl}_{3}\right): \delta-0.06(\mathrm{~s}, 12 \mathrm{H}, \mathrm{SiMe}), 0.04(\mathrm{~s}, 3 \mathrm{H}, \mathrm{SiMe}), 0.44\left(\mathrm{t}, \mathrm{J}_{\mathrm{a}}=8.4 \mathrm{~Hz}, 4 \mathrm{H}\right.$, $\left.\mathrm{SiCH}_{2} \mathrm{CH}_{2} \mathrm{CH}_{2} \mathrm{~N}\right), \quad 0.57$ (m, $10 \mathrm{H}, \quad \mathrm{SiCH}_{2} \mathrm{CH}_{2} \mathrm{CH}_{2} \mathrm{Si}$ and $\left.\mathrm{ClCH}_{2} \mathrm{CH}_{2} \mathrm{CH}_{2} \mathrm{Si}\right), \quad 1.29$ (m, $4 \mathrm{H}$, $\mathrm{SiCH}_{2} \mathrm{CH}_{2} \mathrm{CH}_{2} \mathrm{Si}$ ), $1.42\left(\mathrm{~m}, 4 \mathrm{H}, \mathrm{SiCH}_{2} \mathrm{CH}_{2} \mathrm{CH}_{2} \mathrm{~N}\right), 1.72\left(\mathrm{~m}, 2 \mathrm{H}, \mathrm{ClCH}_{2} \mathrm{CH}_{2}\right), 2.19$ (m, $16 \mathrm{H}, \mathrm{CH}_{2} \mathrm{NMe}_{2}$ ), $3.47\left(\mathrm{t}, \mathrm{J}_{\mathrm{b}}=6.9 \mathrm{~Hz}, 2 \mathrm{H}, \mathrm{ClCH}_{2}\right) .{ }^{13} \mathrm{C}\left\{{ }^{1} \mathrm{H}\right\}-\mathrm{NMR}\left(\mathrm{CDCl}_{3}\right): \delta \quad-5.2(\mathrm{SiMe}),-3.4\left(\mathrm{Si}_{2}\right), 11.6$ $\left(\mathrm{ClCH}_{2} \mathrm{CH}_{2} \mathrm{CH}_{2} \mathrm{Si}\right), \quad 12.8 \quad\left(\mathrm{SiCH}_{2} \mathrm{CH}_{2} \mathrm{CH}_{2} \mathrm{~N}\right), \quad 18.3, \quad 18.5$ and $20.0 \quad\left(\mathrm{SiCH}_{2} \mathrm{CH}_{2} \mathrm{CH}_{2} \mathrm{Si}\right), \quad 22.1$ $\left(\mathrm{SiCH}_{2} \mathrm{CH}_{2} \mathrm{CH}_{2} \mathrm{NMe}_{2}\right), 27.7\left(\mathrm{ClCH}_{2} \mathrm{CH}_{2}\right), 45.5\left(-\mathrm{NMe}_{2}\right), 48.1\left(\mathrm{ClCH}_{2}\right), 63.4\left(\mathrm{CH}_{2} \mathrm{NMe}_{2}\right) . \mathrm{MS}:[\mathrm{M}+\mathrm{H}]^{+}=$ 493.4 uma (calcd. $=493.4$ uma). Anal. Calc. $\mathrm{C}_{24} \mathrm{H}_{57} \mathrm{ClN}_{2} \mathrm{Si}_{3}(493.43 \mathrm{~g} / \mathrm{mol}): \mathrm{C}, 58.42 ; \mathrm{H}, 11.64 ; \mathrm{N}, 5.68$; Exp.: C, 58.89; H, 11.57; N, 5.81.

$\mathrm{ClG}_{2}\left(\mathbf{S i}-\mathrm{NMe}_{2}\right)_{\mathbf{4}}$ (12). This product was synthesized following the synthetic procedure described for $\mathbf{1 1}$ from $\mathrm{ClG}_{2}(\mathrm{SiH})_{4}(0.512 \mathrm{~g}, 0.74 \mathrm{mmol})$ and $\mathrm{C}_{3} \mathrm{H}_{5} \mathrm{NMe}_{2}(0.70 \mathrm{~mL}, 5.91 \mathrm{mmol})$, giving 12 as yellowish oil $(0.763 \mathrm{~g}, 99 \%)$.

${ }^{1} \mathrm{H}-\mathrm{NMR}\left(\mathrm{CDCl}_{3}\right): \delta-0.07$ (s, $24 \mathrm{H}, \mathrm{SiMe}$ ), 0.03 (s, $\left.9 \mathrm{H}, \mathrm{SiMe}\right), 0.45\left(\mathrm{~m}, 8 \mathrm{H}, \mathrm{SiCH}_{2} \mathrm{CH}_{2} \mathrm{CH}_{2} \mathrm{~N}\right), 0.56$ (m, $26 \mathrm{H}, \mathrm{SiCH}_{2} \mathrm{CH}_{2} \mathrm{CH}_{2} \mathrm{Si}$ and $\mathrm{ClCH}_{2} \mathrm{CH}_{2} \mathrm{CH}_{2} \mathrm{Si}$, overlapped), 1.30 (m, $8 \mathrm{H}, \mathrm{SiCH}_{2} \mathrm{CH}_{2} \mathrm{CH}_{2} \mathrm{Si}$ ), 1.41 (m, 8 $\left.\mathrm{H}, \mathrm{SiCH}_{2} \mathrm{CH}_{2} \mathrm{CH}_{2} \mathrm{~N}\right), 1.73\left(\mathrm{~m}, 2 \mathrm{H}, \mathrm{ClCH}_{2} \mathrm{CH}_{2}\right), 2.18\left(\mathrm{~m}, 32 \mathrm{H},-\mathrm{NMe} e_{2}\right.$ and $\left.\mathrm{CH}_{2} \mathrm{NMe}_{2}\right), 3.46\left(\mathrm{t}, \mathrm{J}_{\mathrm{b}}=6.8 \mathrm{~Hz}\right.$, $\left.2 \mathrm{H}, \mathrm{ClCH} \mathrm{H}_{2}\right) .{ }^{13} \mathrm{C}\left\{{ }^{1} \mathrm{H}\right\}-\mathrm{NMR}\left(\mathrm{CDCl}_{3}\right): \delta-5.1$ and $-5.0\left(\mathrm{SiCH}_{3}\right),-3.3\left(\mathrm{SiMe}_{2}\right), 11.6\left(\mathrm{ClCH}_{2} \mathrm{CH}_{2} \mathrm{CH}_{2} \mathrm{Si}\right), 12.9$ $\left(\mathrm{SiCH}_{2} \mathrm{CH}_{2} \mathrm{CH}_{2} \mathrm{~N}\right)$, 18.4-20.1 $\left(\mathrm{SiCH}_{2} \mathrm{CH}_{2} \mathrm{CH}_{2} \mathrm{Si}\right), 22.1\left(\mathrm{SiCH}_{2} \mathrm{CH}_{2} \mathrm{CH}_{2} \mathrm{NMe}_{2}\right), 27.8\left(\mathrm{ClCH}_{2} \mathrm{CH}_{2}\right), 45.5(-$ $\left.\mathrm{NMe}_{2}\right), 48.1\left(\mathrm{ClCH}_{2}\right), 63.4\left(\mathrm{CH}_{2} \mathrm{NMe}_{2}\right) .{ }^{29} \mathrm{Si}-\mathrm{NMR}\left(\mathrm{CDCl}_{3}\right): \delta 2.1\left(\mathrm{G}_{1} \mathrm{SiMe}\right), 0.9\left(\mathrm{G}_{2}-\mathrm{SiMe}\right), 1.9\left(\mathrm{G}_{2}-\right.$ Si $\left.\mathrm{Me}_{2}\right) . \mathrm{MS}:[\mathrm{M}+\mathrm{H}]^{+}=1035.8$ uma (calcd. $=1035.8$ uma).Anal. Calc. $\mathrm{C}_{52} \mathrm{H}_{123} \mathrm{ClN}_{4} \mathrm{Si}_{7}(1036.61 \mathrm{~g} / \mathrm{mol}): \mathrm{C}$, 60.25; H, 11.96; N, 5.40; Exp.: C, 58.53; H, 11.10; N, 4.62. 
$\mathbf{C l G}_{1}\left(\mathbf{S i}_{-N M \mathbf{H}_{3}}\right)_{2}$ (13). A mixture of $11(0.220 \mathrm{~g}, 0.44 \mathrm{mmol})$ and MeI $(0.11 \mathrm{~mL}, 1.76 \mathrm{mmol})$ in THF $(50 \mathrm{~mL})$ were stirred for $16 \mathrm{~h}$. Afterwards, volatiles were removed under vacuum and the remaining solid was washed with $\mathrm{Et}_{2} \mathrm{O}(50 \mathrm{~mL})$, obtaining 13 as a white solid $(0.300 \mathrm{~g}, 87 \%)$.

${ }^{1} \mathrm{H}-\mathrm{NMR}\left(\mathrm{DMSO}_{6}\right.$ ): $\delta-0.07$ (s, $3 \mathrm{H}, \mathrm{SiMe}$ ), 0.00 (s, $12 \mathrm{H}, \mathrm{SiMe}$ ), 0.38 and $0.56\left(\mathrm{~m}, 14 \mathrm{H}, \mathrm{SiCH}{ }_{2}\right.$ ), $1.31\left(\mathrm{~m}, 4 \mathrm{H}, \mathrm{SiCH}_{2} \mathrm{CH}_{2} \mathrm{CH}_{2} \mathrm{Si}\right), 1.62\left(\mathrm{~m}, 6 \mathrm{H}, \mathrm{CH}_{2} \mathrm{CH}_{2} \mathrm{~N}^{+}\right.$and $\left.\mathrm{ClCH}_{2} \mathrm{CH}_{2}\right), 3.05\left(\mathrm{~s}, 18 \mathrm{H},-\mathrm{NMe}{ }_{3}^{+}\right), 3.25(\mathrm{t}$, $\left.\mathrm{J}_{\mathrm{a}}=7.8 \mathrm{~Hz}, 4 \mathrm{H}, \mathrm{CH}_{2} \mathrm{~N}^{+}\right), 2.58\left(\mathrm{t}, \mathrm{J}_{\mathrm{b}}=6.5 \mathrm{~Hz}, \mathrm{ClCH} 2\right) .{ }^{13} \mathrm{C}\left\{{ }^{1} \mathrm{H}\right\}-\mathrm{NMR}\left(\mathrm{DMSO}-\mathrm{d}_{6}\right): \delta-5.6(\mathrm{SiMe}),-3.9$ ( $\mathrm{SiMe}$ ), $10.6\left(\mathrm{SiCH}_{2} \mathrm{CH}_{2} \mathrm{CH}_{2} \mathrm{~N}^{+}\right)$, 16.4-17.4 $\left(\mathrm{SiCH}_{2} \mathrm{CH}_{2} \mathrm{CH}_{2} \mathrm{Si}\right), 18.6\left(\mathrm{CH}_{2} \mathrm{CH}_{2} \mathrm{~N}^{+}\right), 26.7\left(\mathrm{ClCH}_{2} \mathrm{CH}_{2}\right), 47.8$ $\left(\mathrm{ClCH}_{2}\right), 51.6\left(-\mathrm{NMe}_{3}{ }^{+}\right), 67.4\left(\mathrm{SiCH}_{2} \mathrm{CH}_{2} \mathrm{CH}_{2} \mathrm{NMe}_{3}{ }^{+}\right) .{ }^{29} \mathrm{Si}-\mathrm{NMR}\left(\mathrm{DMSO}-\mathrm{d}_{6}\right): \delta 2.1(\mathrm{SiMe}), 2.4\left(\mathrm{SiMe}_{2}\right)$. ESI: $(776.21 \mathrm{~g} / \mathrm{mol}) \mathrm{q}=1\left(649.31[\mathrm{M}-\mathrm{I}]^{+}\right)$. Anal. Calc. $\mathrm{C}_{26} \mathrm{H}_{63} \mathrm{ClI}_{2} \mathrm{~N}_{2} \mathrm{Si}_{3}(777.31 \mathrm{~g} / \mathrm{mol}): \mathrm{C}, 40.17 ; \mathrm{H}, 8.17$; N, 3.60; Exp.: C, 40.78; H, 8.39; N, 3.93.

$\mathrm{ClG}_{2}\left(\mathrm{Si}_{-} \mathrm{NMe}_{3}\right)_{4}$ (14). This product was synthesized following the synthetic procedure described for 13 from $12(0.638 \mathrm{~g}, 0.62 \mathrm{mmol})$ and $\mathrm{MeI}(0.16 \mathrm{~mL}, 2.59 \mathrm{mmol})$, which led to 14as white solid (0.805 g, $81 \%)$.

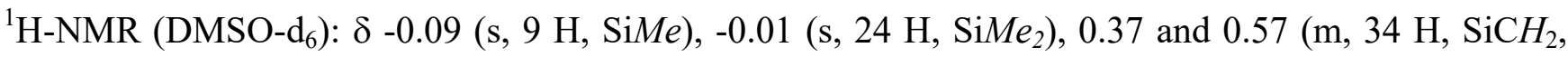
overlapped), $1.30\left(\mathrm{~m}, 12 \mathrm{H}, \mathrm{SiCH}_{2} \mathrm{CH}_{2} \mathrm{CH}_{2} \mathrm{Si}\right), 1.61\left(\mathrm{~m}, 10 \mathrm{H}, \mathrm{CH}_{2} \mathrm{CH}_{2} \mathrm{~N}^{+}\right.$and $\left.\mathrm{ClCH}_{2} \mathrm{CH}_{2}\right), 3.03(\mathrm{~s}, 36 \mathrm{H},-$ $\left.\mathrm{NMe}_{3}{ }^{+}\right), 3.23\left(\mathrm{t}, \mathrm{J}_{\mathrm{a}}=8.3 \mathrm{~Hz}, 8 \mathrm{H}, \mathrm{CH}_{2} \mathrm{~N}^{+}\right), 3.57\left(\mathrm{t}, \mathrm{J}_{\mathrm{b}}=6.4 \mathrm{~Hz}, 2 \mathrm{H}, \mathrm{ClCH}_{2}\right) .{ }^{13} \mathrm{C}\left\{{ }^{1} \mathrm{H}\right\}-\mathrm{NMR}\left(\mathrm{DMSO}-\mathrm{d}_{6}\right): \delta$ -5.3 ( $\mathrm{SiMe}),-3.9\left(\mathrm{SiMe}_{2}\right), 10.7\left(\mathrm{SiCH}_{2} \mathrm{CH}_{2} \mathrm{CH}_{2} \mathrm{~N}^{+}\right), 16.4-17.7\left(\mathrm{SiCH}_{2} \mathrm{CH}_{2} \mathrm{CH}_{2} \mathrm{Si}\right), 18.8\left(\mathrm{CH}_{2} \mathrm{CH}_{2} \mathrm{~N}^{+}\right), 26.7$ $\left(\mathrm{ClCH}_{2} \mathrm{CH}_{2}\right), 47.8\left(\mathrm{ClCH}_{2}\right), 51.6\left(\mathrm{NMe}_{3}{ }^{+}\right), 67.4\left(\mathrm{SiCH}_{2} \mathrm{CH}_{2} \mathrm{CH}_{2} \mathrm{NMe}_{3}{ }^{+}\right) .{ }^{29} \mathrm{Si}-\mathrm{NMR}\left(\mathrm{CDCl}_{3}\right): \delta 2.2\left(\mathrm{G}_{1}-\mathrm{Si}\right)$, $1.1\left(\mathrm{G}_{2}-\mathrm{SiMe}\right), 2.4\left(\mathrm{G}_{2}-\mathrm{SiMe}_{2}\right)$. ESI: $\mathrm{q}=2\left(674.35 ;[\mathrm{M}-2 \mathrm{I}]^{2+}\right), \mathrm{q}=3\left(407.28 ;[\mathrm{M}-3 \mathrm{I}]^{3+}\right)$ and $\mathrm{q}=4(273.7$; $[\mathrm{M}-$ 4I $\left.]^{4+}\right)$. Anal. Calc. $\mathrm{C}_{56} \mathrm{H}_{135} \mathrm{ClI}_{4} \mathrm{~N}_{4} \mathrm{Si}_{7}(1604.37 \mathrm{~g} / \mathrm{mol}): \mathrm{C}, 41.92 ; \mathrm{H}, 8.48 ; \mathrm{N}, 3.49$; Exp.: C, 42.22; H, 8.27; N, 3.46 .

$\left(\right.$ PenV)G $\mathbf{G}_{1}\left(\mathrm{Si}_{-} \mathrm{NMe}_{3} \mathrm{I}\right)_{2} \mathbf{2}$ (15). To a solution of $13(0.050 \mathrm{~g}, 0.06 \mathrm{mmol})$ in dry DMF, PenVK (0.027 g, $0.07 \mathrm{mmol})$ was added in the presence of $18 \mathrm{C} 6(0.002 \mathrm{~g}, 0.01 \mathrm{mmol})$ and a catalytic amount of NaI. The mixture was heated at $80^{\circ} \mathrm{C}$ in a sealed ampoule under argon atmosphere for 2 nights after which volatiles 
were removed. After washing the residues with water, dendron $\mathbf{1 5}$ was obtained as a very hygroscopic white solid $(0.062 \mathrm{~g}, 89 \%)$.

${ }^{1} \mathrm{H}-\mathrm{NMR}\left(\mathrm{CDCl}_{3}\right): \delta 0.00$ (s, $12 \mathrm{H}, \mathrm{SiMe}$ ), 0.04 (s, $\left.3 \mathrm{H}, \mathrm{SiMe}\right), 0.57$ (m, $14 \mathrm{H}, \mathrm{SiCH}_{2}$ ), 1.29 (m, 4 H, $\left.\mathrm{SiCH}_{2} \mathrm{CH}_{2} \mathrm{CH}_{2} \mathrm{Si}\right), 1.48\left(\mathrm{~s}, 3 \mathrm{H}, \mathrm{CMe}_{2}\right), 1.58\left(\mathrm{~s}, 3 \mathrm{H}, \mathrm{CMe}_{2}\right), 1.70\left(\mathrm{~m}, 6 \mathrm{H}, \mathrm{CH}_{2} \mathrm{CH}_{2} \mathrm{~N}^{+}\right.$and $\left.\mathrm{OCH}_{2} \mathrm{CH}_{2}\right), 3.41$ $\left(\mathrm{s}, 18 \mathrm{H},-\mathrm{NMe}_{3}{ }^{+}\right), 3.63\left(\mathrm{~m}, 4 \mathrm{H}, \mathrm{CH}_{2} \mathrm{~N}^{+}\right), 4.08\left(\mathrm{t}, \mathrm{J}_{\mathrm{a}}=8.4 \mathrm{~Hz}, 2 \mathrm{H},(\mathrm{CO}) \mathrm{OCH} H_{2}\right), 4.43\left(\mathrm{~s}, 1 \mathrm{H}, \mathrm{CH}\left(\mathrm{CMe}_{2}\right)\right)$, $4.53\left(\mathrm{~s}, 2 \mathrm{H}, \mathrm{OCH}_{2} \mathrm{CO}\right), 5.56\left(\mathrm{~d}, \mathrm{~J}_{\mathrm{b}}=4.3 \mathrm{~Hz}, 1 \mathrm{H}, \mathrm{CHS}\right), 5.70(\mathrm{~m}, 1 \mathrm{H}, \mathrm{NHCH}), 6.90\left(\mathrm{~d}, \mathrm{~J}_{\mathrm{c}}=7.6 \mathrm{~Hz}, 2 \mathrm{H}\right.$, $\left.\mathrm{CH}_{\mathrm{Ar}}\right), 7.01\left(\mathrm{t}, \mathrm{J}_{\mathrm{d}}=7.4 \mathrm{~Hz}, 1 \mathrm{H}, \mathrm{C} H_{\mathrm{Ar}}\right), 7.30\left(\mathrm{~m}, 2 \mathrm{H}, \mathrm{C} H_{\mathrm{Ar}}\right) .{ }^{13} \mathrm{C}\left\{{ }^{1} \mathrm{H}\right\}-\mathrm{NMR}\left(\mathrm{CDCl}_{3}\right): \delta-5.0\left(\mathrm{SiCH}_{3}\right),-3.2$ (SiMe $)$, $9.9\left(\mathrm{CH}_{2} \mathrm{Si}\right), 11.4\left(\mathrm{SiCH}_{2} \mathrm{CH}_{2} \mathrm{CH}_{2} \mathrm{~N}^{+}\right), 17.9,18.0$ and $18.3\left(\mathrm{SiCH}_{2} C_{2} \mathrm{CH}_{2} \mathrm{Si}\right), 19.8\left(\mathrm{CH}_{2} \mathrm{CH}_{2} \mathrm{~N}^{+}\right)$, $23.2\left(\mathrm{OCH}_{2} \mathrm{CH}_{2}\right), 26.8$ and $32.0\left(\mathrm{SCMe}_{2}\right), 53.7\left(-\mathrm{NMe}_{3}{ }^{+}\right), 58.0(\mathrm{NHCH}), 64.7\left(\mathrm{SCMe}_{2}\right), 67.1\left(\mathrm{CH}_{2} \mathrm{~N}^{+}\right), 67.7$ $\left(\mathrm{OCH}_{2} \mathrm{CO}\right), 68.4\left(\mathrm{COOCH}_{2}\right), 69.5(C \mathrm{HS}), 70.5(C \mathrm{HCOO}), 114.7\left(\mathrm{CH}_{\mathrm{Ar}}\right), 122.4\left(\mathrm{CH}_{\mathrm{Ar}}\right), 129.8\left(C \mathrm{H}_{\mathrm{Ar}}\right)$, $156.8\left(\mathrm{CO}_{\mathrm{Ar}}\right), 167.6,167.8$ and $173.0(C=\mathrm{O})$. ESI: $(1090.32 \mathrm{~g} / \mathrm{mol}) \mathrm{q}=1\left(963.42[\mathrm{M}-\mathrm{I}]^{+}\right), \mathrm{q}=2(418.26$ $\left.[\mathrm{M}-2 \mathrm{I}]^{2+}\right)$. Anal. Calc. $\mathrm{C}_{42} \mathrm{H}_{80} \mathrm{I}_{2} \mathrm{~N}_{4} \mathrm{O}_{5} \mathrm{SSi}_{3}(1091.24 \mathrm{~g} / \mathrm{mol}): \mathrm{C}, 46.23 ; \mathrm{H}, 7.39 ; \mathrm{N}, 5.13$; Exp.: C, 45.94; H, 7.07; N, 4.43 .

$(\mathrm{PenV}) \mathbf{G}_{\mathbf{2}}\left(\mathrm{Si}_{-} \mathrm{NMe}_{3} \mathrm{I}\right)_{4}(\mathbf{1 6})$. This product was synthesized following the synthetic procedure described for 15 from $14(0.120 \mathrm{~g}, 0.07 \mathrm{mmol}), \mathrm{PenCO}_{2} \mathrm{~K}(0.030 \mathrm{~g}, 0.08 \mathrm{mmol})$ and $18 \mathrm{C} 6(0.002 \mathrm{~g}, 0.01 \mathrm{mmol})$ but heating at $100^{\circ} \mathrm{C}$, obtaining 16 as a highly hygroscopic white solid $(0.136 \mathrm{~g}, 95 \%)$. In this case purification was performed using dyalysis with a membrane of MWCO of 500.

${ }^{1} \mathrm{H}-\mathrm{NMR}\left(\mathrm{DMSO}-\mathrm{d}_{6}\right.$ ): $\delta$-0.13 (s, $9 \mathrm{H}, \mathrm{SiMe}$ ), 0.00 (s, $24 \mathrm{H}, \mathrm{SiMe}$ ), 0.41 and 0.57 (m, $34 \mathrm{H}, \mathrm{SiCH}_{2}$ ), $1.27\left(\mathrm{~m}, 12 \mathrm{H}, \mathrm{SiCH}_{2} \mathrm{CH}_{2} \mathrm{CH}_{2} \mathrm{Si}\right), 1.61\left(\mathrm{~m}, 16 \mathrm{H}, \mathrm{CMe}_{2}, \mathrm{CH}_{2} \mathrm{CH}_{2} \mathrm{~N}^{+}\right.$and $\left.\mathrm{OCH}_{2} \mathrm{CH}_{2}\right), 3.07(\mathrm{~s}, 36 \mathrm{H},-$ $\left.\mathrm{NMe}_{3}{ }^{+}\right), 3.21\left(\mathrm{~m}, 8 \mathrm{H}, \mathrm{CH}_{2} \mathrm{~N}^{+}\right), 4.07\left(\mathrm{~m}, 2 \mathrm{H},(\mathrm{CO}) \mathrm{OCH}_{2}\right), 4.41(\mathrm{~s}, 1 \mathrm{H}, \mathrm{CH}(\mathrm{CO})), 4.58\left(\mathrm{~s}, 2 \mathrm{H}, \mathrm{OCH} \mathrm{CO}_{2}\right)$, $5.57(\mathrm{~m}, 1 \mathrm{H}, \mathrm{CHS}), 5.61(\mathrm{~m}, 1 \mathrm{H}, \mathrm{NHCH}), 6.97\left(\mathrm{~m}, 3 \mathrm{H}, \mathrm{C} H_{\mathrm{Ar}}\right), 7.31\left(\mathrm{~m}, 2 \mathrm{H}, \mathrm{C} H_{\mathrm{Ar}}\right) .{ }^{13} \mathrm{C}\left\{{ }^{1} \mathrm{H}\right\}-\mathrm{NMR}$ (DMSO-d $\left.)_{6}\right): \delta$-5.6 and -5.4 (SiMe), -3.9 $\left(\mathrm{SiMe}_{2}\right), 8.9\left(\mathrm{OCH}_{2} \mathrm{CH}_{2} \mathrm{CH}_{2} \mathrm{Si}\right), 10.6\left(\mathrm{SiCH}_{2} \mathrm{CH}_{2} \mathrm{CH}_{2} \mathrm{~N}^{+}\right), 16.4-$ $17.7\left(\mathrm{SiCH}_{2} \mathrm{CH}_{2} \mathrm{CH}_{2} \mathrm{Si}\right), 18.7\left(\mathrm{CH}_{2} \mathrm{CH}_{2} \mathrm{~N}^{+}\right), 22.1\left(\mathrm{OCH}_{2} \mathrm{CH}_{2}\right.$ and $\left.\mathrm{SC}(M e)_{2}\right), 51.6\left(-\mathrm{NMe}_{3}{ }^{+}\right), 57.9(\mathrm{NHCH})$, $63.5\left(\mathrm{SCMe}_{2}\right), 65.6\left(\mathrm{OCH}_{2} \mathrm{CO}\right), 66.9\left(\mathrm{OCH}_{2}\right), 67.4\left(\mathrm{CH}_{2} \mathrm{~N}^{+}\right), 69.4(C \mathrm{HCOO}), 113.9\left(\mathrm{CH}_{\mathrm{Ar}}\right), 120.7\left(C \mathrm{H}_{\mathrm{Ar}}\right)$, $129.0\left(\mathrm{CH}_{\mathrm{Ar}}\right), 157.0\left(\mathrm{CO}_{\mathrm{Ar}}\right), 167.2,167.3$, and $172.5(\mathrm{C}=\mathrm{O}) .{ }^{29} \mathrm{Si}-\mathrm{NMR}\left(\mathrm{DMSO}-\mathrm{d}_{6}\right): \delta 1.1\left(\mathrm{G}_{2}-\mathrm{SiMe}\right) 2.2$ 
$\left(\mathrm{G}_{1}-\mathrm{SiMe}\right), 2.4\left(\mathrm{G}_{2}-\mathrm{SiMe} \mathrm{Me}_{2}\right)$ ESI: q=2 (831.4; $\left.[\mathrm{M}-2 \mathrm{I}]^{2+}\right), \mathrm{q}=3\left(512.0 ;[\mathrm{M}-3 \mathrm{I}]^{3+}\right)$ and $\mathrm{q}=4\left(352.2 ;[\mathrm{M}-4 \mathrm{I}]^{4+}\right)$.

Anal. Calc. $\mathrm{C}_{72} \mathrm{H}_{152} \mathrm{I}_{4} \mathrm{~N}_{6} \mathrm{O}_{5} \mathrm{SSi}_{7}(1918.29 \mathrm{~g} / \mathrm{mol}): \mathrm{C}, 45.08 ; \mathrm{H}, 7.99 ; \mathrm{N}, 4.38$; Exp.: C, 42.50; H, 8.58; N, 4.97.

\section{S.2. References}

1. Fuentes-Paniagua, E.; Peña-González, C. E.; Galán, M.; Gómez, R.; de la Mata, F. J.; SánchezNieves, J. Organometallics 2013, 32, 1789-1796.

2. $\quad$ Fuentes-Paniagua, E.; Sánchez-Nieves, J.; Fernández-Ezequiel, A.; Hernández-Ros, J. M.; Soliveri, J.; Copa-Patiño, J. L.; Gómez, R.; de la Mata, F. J. RSC Adv. 2016, 6, 7022-7033.

3. Downing, C. M.; Missaghi, M. N.; Kung, M. C.; Kung, H. H. Tetrahedron 2011, 67, 7502-7509.

4. Wolf, C.; Pirkle, W. H. J. Chromatogr. A 1998, 799, 177-184.

5. Reference Methods for the testing the "in vitro" activity of antimicrobial agents against bacteria involved in infectious diseases 2006, ISO 20776-1.

\section{S.3 Reaction schemes and NMR spectra.}

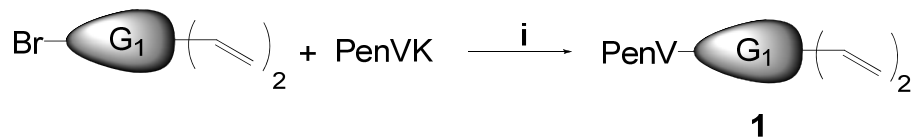

Scheme S1. Synthesis of dendron $(\mathrm{PenV}) \mathrm{G}_{1} \mathrm{~V}_{2}(\mathbf{1})$. i) DMF, $90{ }^{\circ} \mathrm{C}$, ether crown 18-C-6.

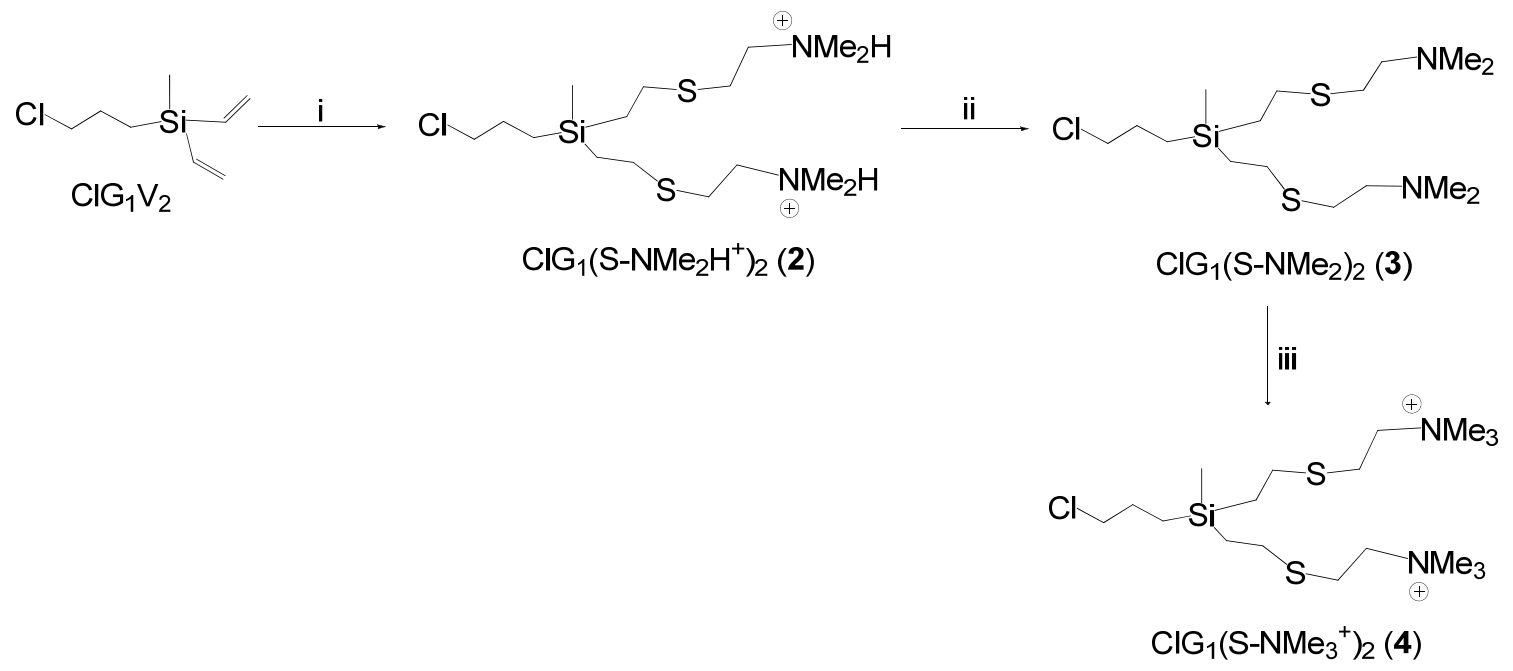

Scheme S2. Synthesis of dendron $\mathrm{ClG}_{1}\left(\mathrm{~S}_{-} \mathrm{NMe}_{3}{ }^{+}\right)(4)$. $) \mathrm{HS}\left(\mathrm{CH}_{2}\right)_{2} \mathrm{NMe}_{2} \cdot \mathrm{HCl}, \mathrm{DMPA}$, hv; ii) $\mathrm{Na}_{2} \mathrm{CO}_{3}$; iii) $\mathrm{MeI}$. 


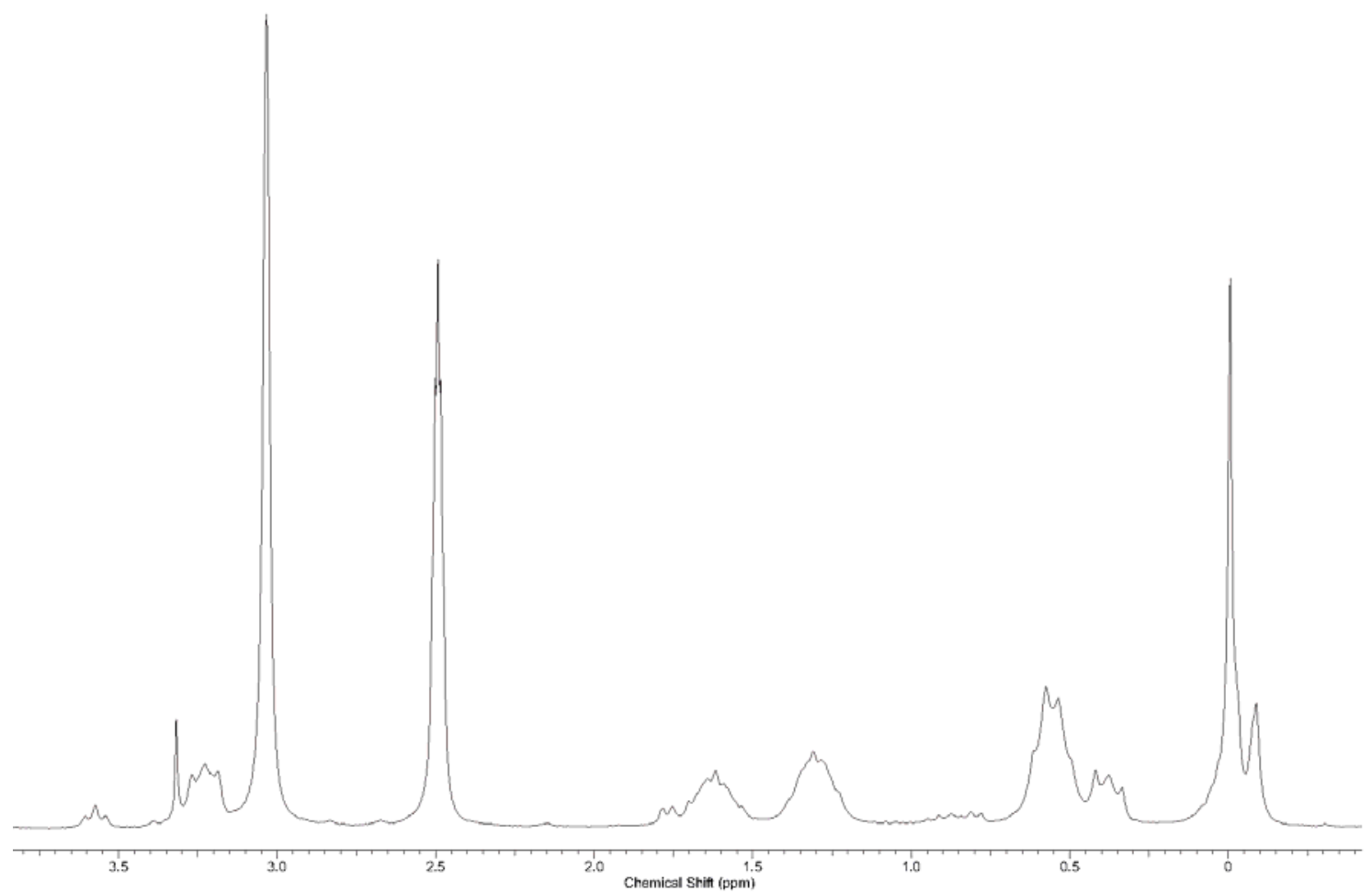

Figure S1. ${ }^{1} \mathrm{H}-\mathrm{NMR}\left(\mathrm{DMSO}-\mathrm{d}_{6}\right)$ spectra of compound $\mathrm{ClG}_{2}\left(\mathrm{Si}_{-\mathrm{NMe}}{ }^{+}\right)_{4}(\mathbf{1 4})$.

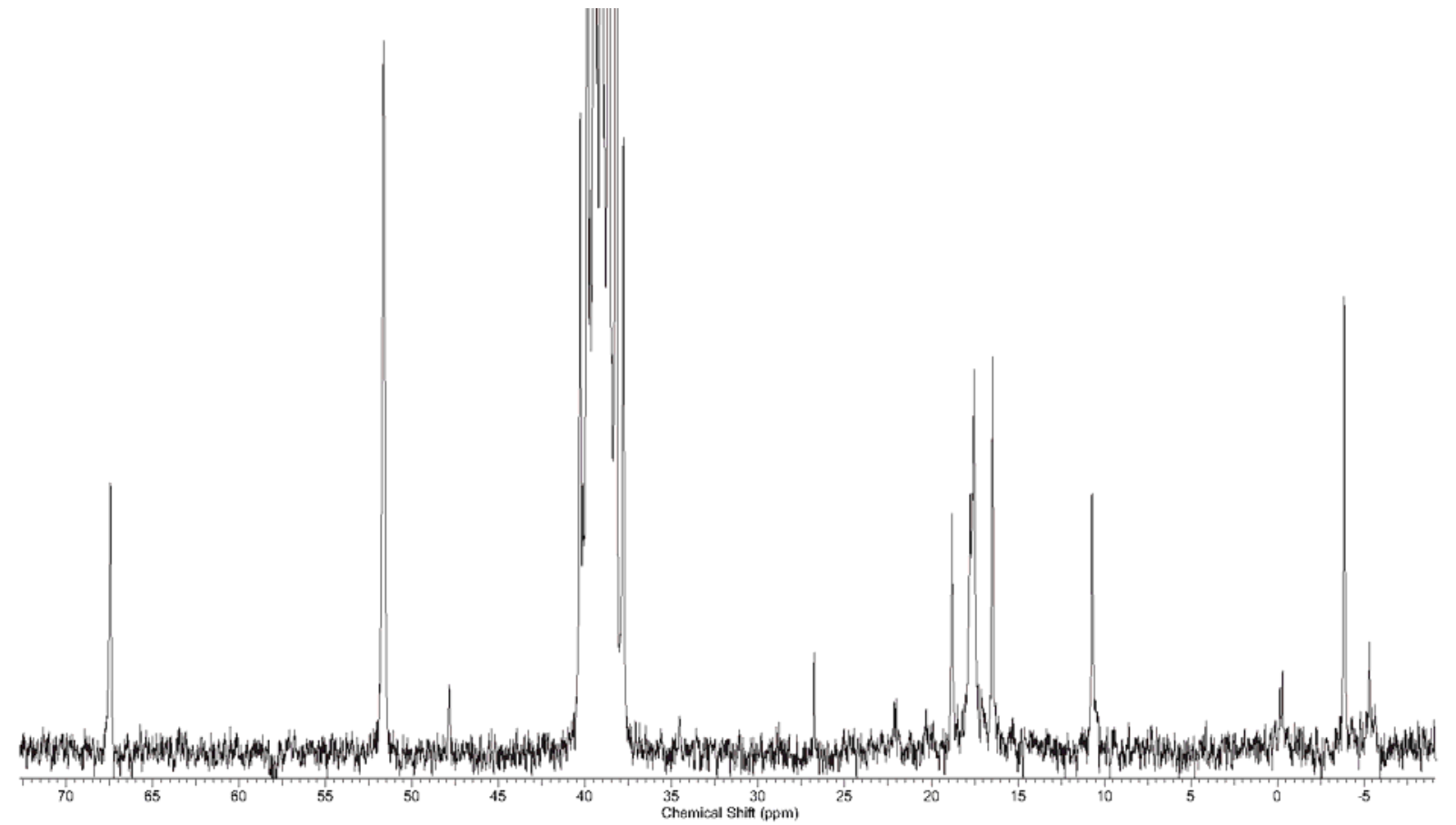

Figure S2. ${ }^{13} \mathrm{C}$ NMR $\left(\right.$ DMSO-d $\left.d_{6}\right)$ spectra of compound $\mathrm{ClG}_{2}\left(\mathrm{Si}-\mathrm{NMe}_{3}{ }^{+}\right)_{4}(\mathbf{1 4})$. 

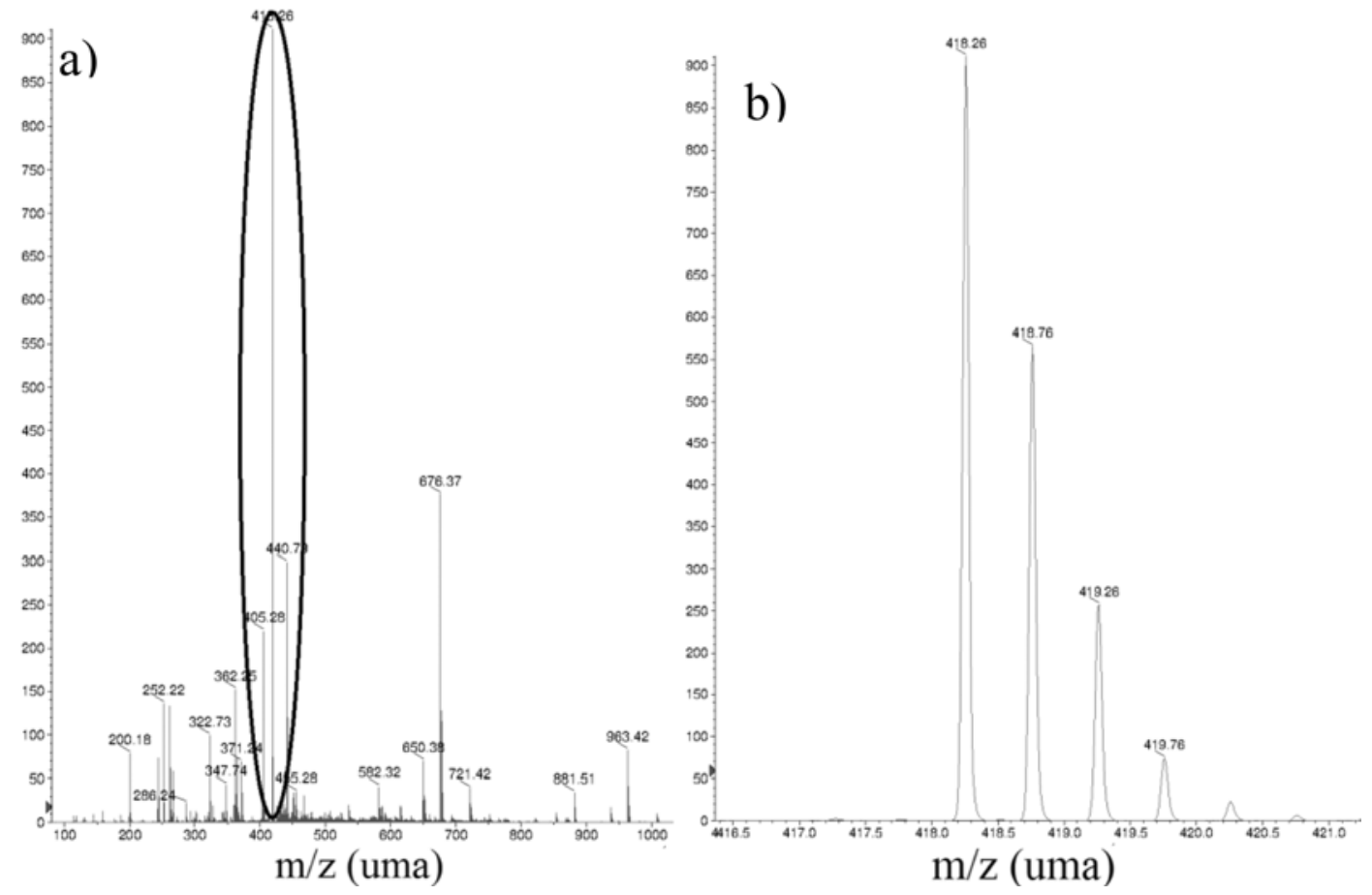

Figure S3. MS spectrum of $\left[(\mathrm{PenV}) \mathrm{G}_{2}\left(\mathrm{Si}_{-}-\mathrm{NMe}_{3}\right)_{4}(\mathrm{I})_{4}\right](\mathbf{1 6})(\mathrm{a})$, observing the presence of the fragment $[\mathrm{M}-$ $2 \mathrm{I}]^{2+}(\mathrm{b})$.

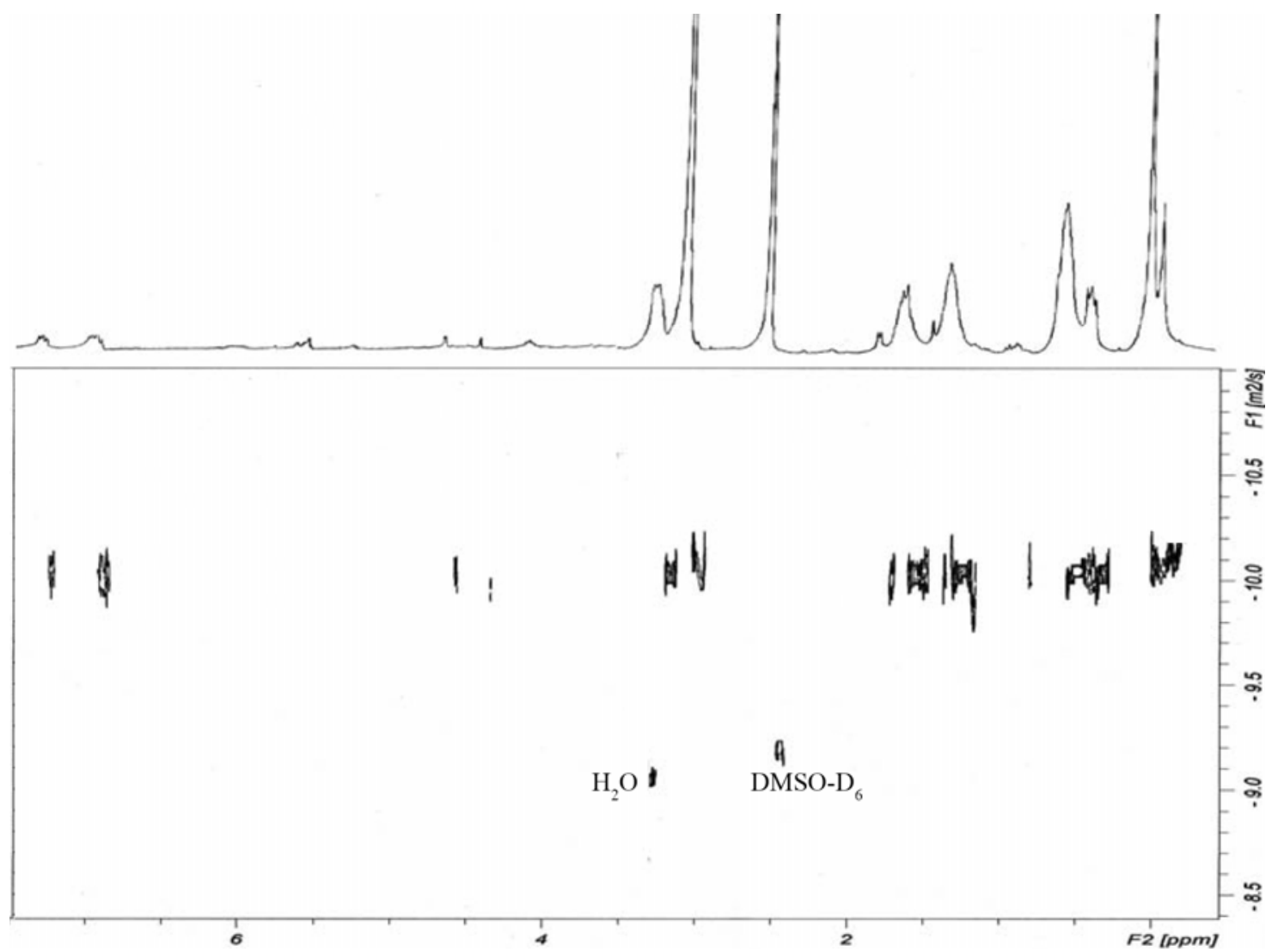

Figure S4. ${ }^{1} \mathrm{H}-\mathrm{NMR}$ and DOSY-2D (DMSO-d $\left.{ }_{6}\right)$ spectra of compound $(\mathrm{PenV}) \mathrm{G}_{2}\left(\mathrm{Si}_{-}-\mathrm{NMe}_{3}{ }^{+}\right)_{4}(\mathbf{1 6})$. 


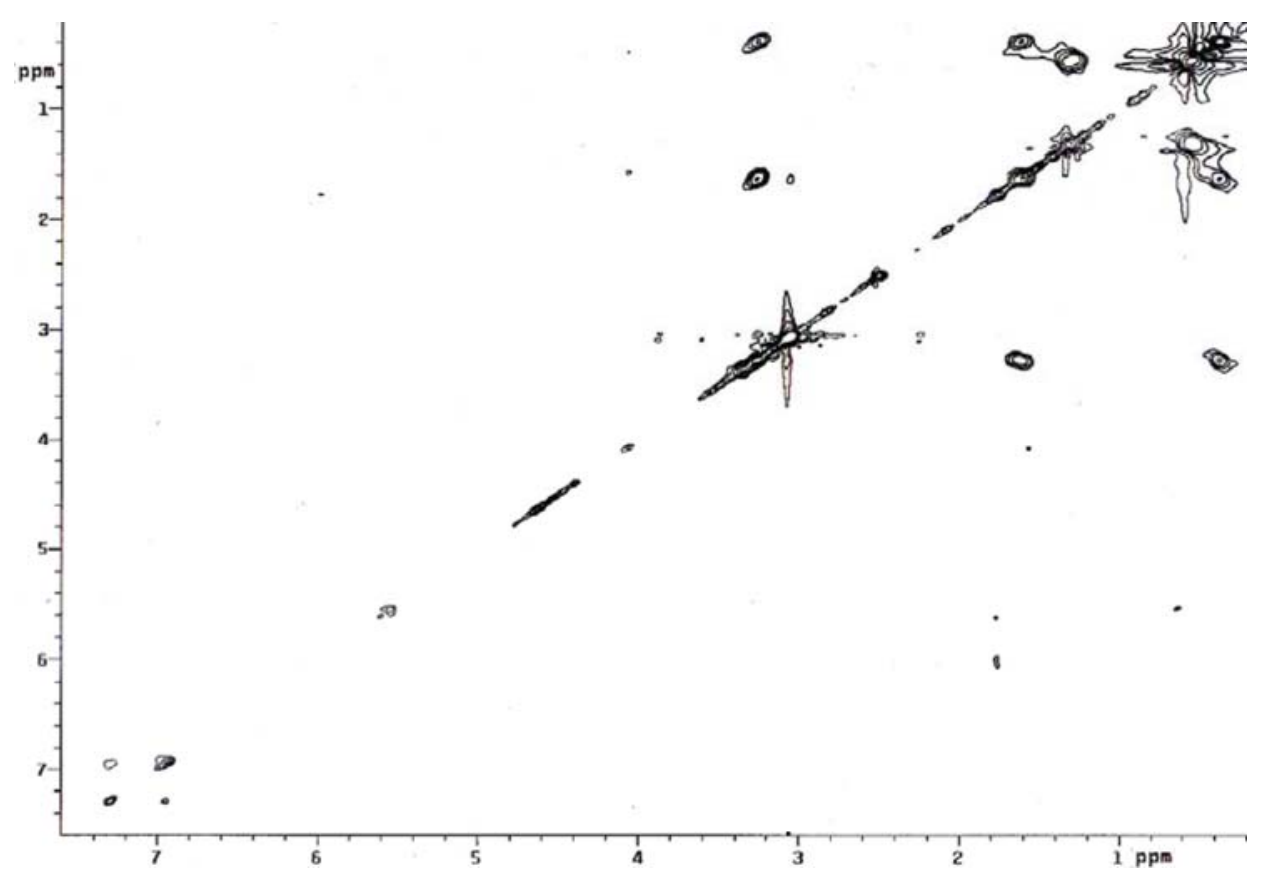

Figure S5. TOCSY (DMSO-d $\left.{ }_{6}\right)$ spectra of compound $(\mathrm{PenV}) \mathrm{G}_{2}\left(\mathrm{Si}_{-}-\mathrm{NMe}_{3}{ }^{+}\right)_{4}(\mathbf{1 6})$.

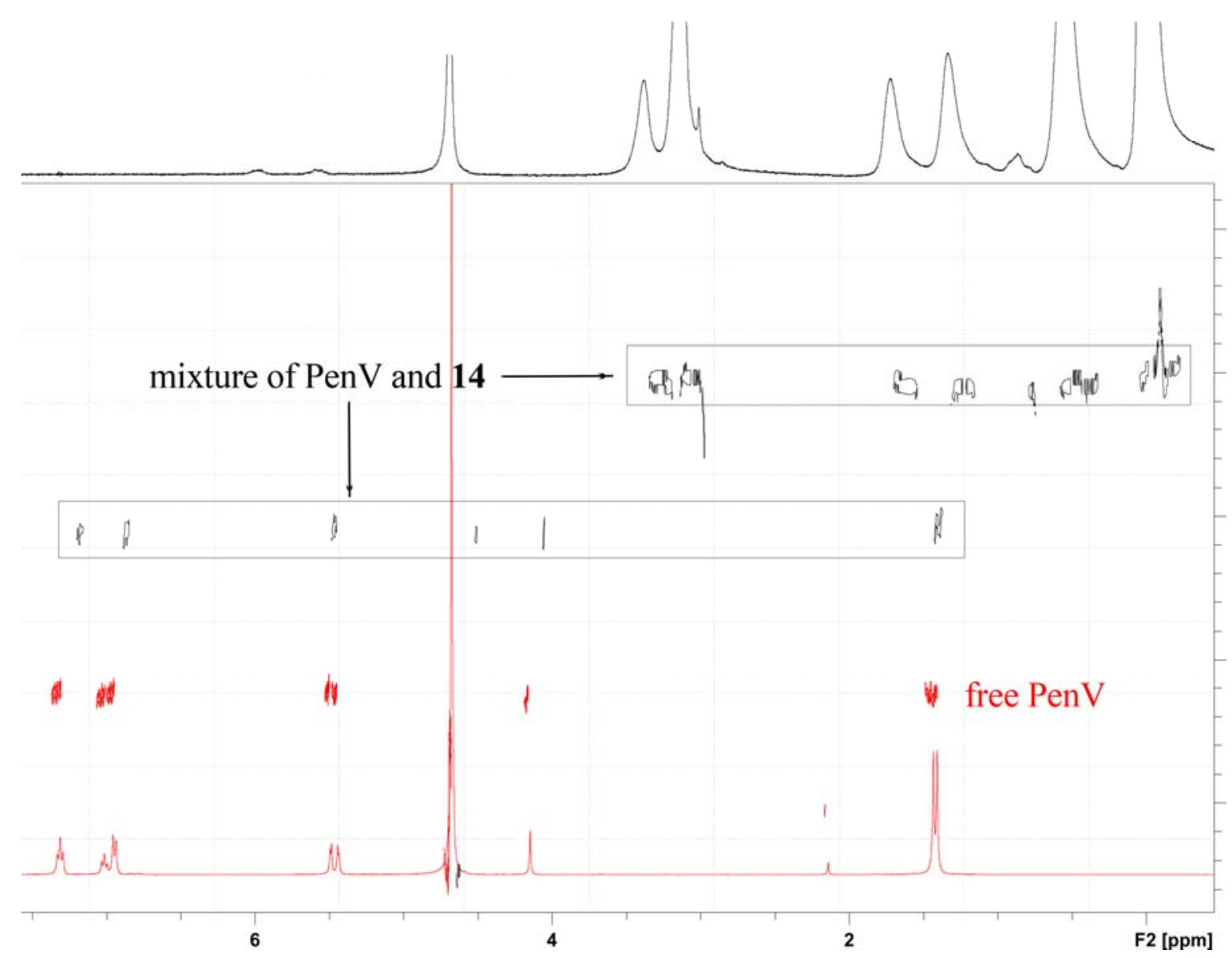

Figure S6. ${ }^{1} \mathrm{H}$ NMR and DOSY $2 \mathrm{D}$ spectra $\left(\mathrm{D}_{2} \mathrm{O}\right)$ of free PenV (red) and ${ }^{1} \mathrm{H}$ NMR and DOSY $2 \mathrm{D}$ spectra $\left(\mathrm{D}_{2} \mathrm{O}\right)$ of an equimolecular mixture of PenVK and dendron $\left[\mathrm{ClG}_{2}\left(\mathrm{Si}_{-}-\mathrm{NMe}_{3}\right)_{4}\right]^{4+}(\mathbf{1 4})($ black$)$. 